\title{
THIAGO SANTIN
}

Avaliação da progressão da microbiota vaginal no período de transição em vacas leiteiras, associada com infecções uterinas.

São Paulo

2018

THIAGO SANTIN 


\section{Avaliação da progressão da microbiota vaginal no período de transição em vacas}

leiteiras, associada com infecções uterinas.

Tese apresentada ao Programa de PósGraduação em Reprodução Animal da

Faculdade de Medicina Veterinária e Zootecnia da Universidade de São Paulo para a obtenção do título de Doutor em Ciências

Departamento:

Reprodução Animal

Área de concentração:

Medicina Veterinária

Orientador:

Prof. Dr. Ed Hoffmann Madureira

De acordo:

Orientador

São Paulo

2018 
Autorizo a reprodução parcial ou total desta obra, para fins acadêmicos, desde que citada a fonte.

\section{DADOS INTERNACIONAIS DE CATALOGAÇÃO NA PUBLICAÇÃO}

(Biblioteca Virginie Buff D’Ápice da Faculdade de Medicina Veterinária e Zootecnia da Universidade de São Paulo)

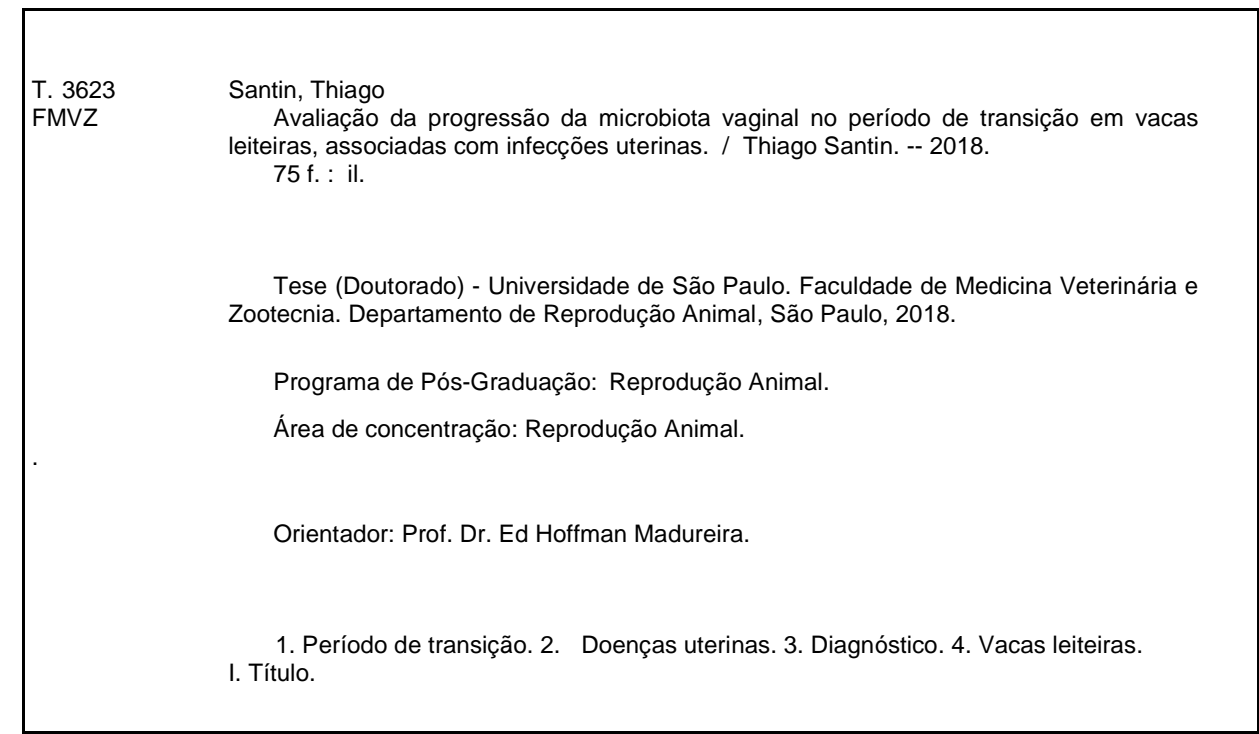

Ficha catalográfica elaborada por Denise Yamashita, CRB-8/8931 


\section{CERTIFICADO}

Certificamos que a proposta intitulada "Avaliação da progressão da microbiota vaginal no período de transição em vacas leiteiras, associada com infecções uterinas.", protocolada sob o CEUA no 7968290114, sob a responsabilidade de Ed Hoffmann Madureira - que envolve a produção, manutenção e/ou utilização de animais pertencentes ao filo Chordata, subfilo Vertebrata (exceto o homem), para fins de pesquisa científica ou ensino - está de acordo com os preceitos da Lei 11.794 de 8 de outubro de 2008 , com o Decreto 6.899 de 15 de julho de 2009, bem como com as normas editadas pelo Conselho Nacional de Controle da Experimentação Animal (CONCEA), e foi aprovada pela Comissão de Ética no Uso de Animais da Faculdade de Medicina Veterinária e Zootecnia da Universidade de São Paulo (CEUA/FMVZ) na reunião de 15/02/2018.

We certify that the proposal " Evaluation of progress of the microbiota found in the vaginas of dairy cows during the transition period: Associations with uterine diseases", utilizing 8 Bovines ( 8 females), protocol number CEUA 7968290114, under the responsibility of Ed Hoffmann Madureira - which involves the production, maintenance and/or use of animals belonging to the phylum Chordata, subphylum Vertebrata (except human beings), for scientific research purposes or teaching - is in accordance with Law 11.794 of October 8, 2008, Decree 6899 of July 15, 2009, as well as with the rules issued by the National Council for Control of Animal Experimentation (CONCEA), and was approved by the Ethic Committee on Animal Use of the School of Veterinary Medicine and Animal Science (University of São Paulo) (CEUA/FMVZ) in the meeting of 02/15/2018.

Finalidade da Proposta: Pesquisa

Vigência da Proposta: de 01/2018 a 02/2018_ Área: Fisiologia

Origem: $\quad$ Prefeitura do Campus da USP de Pirassununga

Espécie: Bovinos sexo: Fêmeas idade: 03 a 10 anos $\quad$ N: 08

Linhagem: nelore $\quad$ Peso: $400 \mathrm{a} 600 \mathrm{~kg}$

Resumo: Comparar a cinética de liberação e concentrações plasmáticas de $m$ dispositivo intravaginal desenvolvimento (contendo $1,4 \mathrm{~g}$ de progesterona) com a do CIDR $®$ (contendo 1,9 de progesterona), de 16 bovnos. Verificar a eficiência para sincronização para IATF, e comparar os resultados de fertilidade. O declínio da fertilidade em vacas leiteiras de alta produção nas últimas décadas tem sido associado ao aumento da ingestão de matéria seca e produção de leite. Vacas em lactação requerem mais energia do que vacas não lactantes. A alta ingestão de matéria seca necessária, leva a um aumento do fluxo sanguíneo hepático e consequentemente uma alta taxa metabolização de E2 e P4, (WILTBANK et al. 2006). Este fato poderia explicar, ao menos em parte, a menor intensidade e duração dos estros expressos por estes animais de alta produção e pela diminuição do pico de E2 (LOPEZ et al., 2004) e aumento na taxa de dupla ovulação (LOPEZ et al., 2005). O dispositivo intravaginal CIDR $®$, foi desenvolvido em 1978 e possuí 1,9 gramas de P4, entretanto libera 0,6 gramas em seu primeiro uso, essa quantidade pode não ser suficiente para vacas de alta produção, pensando nisso, será confeccionado um dispositivo em silicone monodose, contendo 1,4 gramas de P4, o qual devido sua maior área de contato, se espera que libere uma maior quantidads de P4 que a do CIDR ${ }^{\text {. }}$

Local do experimento: curral do CBRA/VRA -USP campus de Pirassununga.

São Paulo, 15 de fevereiro de 2018

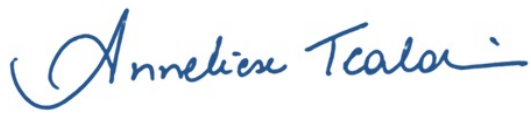

Profa. Dra. Anneliese de Souza Traldi

Presidente da Comissão de Ética no Uso de Animais

Faculdade de Medicina Veterinária e Zootecnia da Universidade de São Paulo

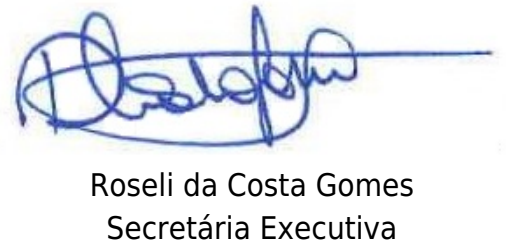

Faculdade de Medicina Veterinária e Zootecnia da Universidade de São Paulo 
IImo(a). Sr(a).

Responsável: Ed Hoffmann Madureira

Área: Fisiologia

Ed Hoffmann Madureira (orientador)

Título da proposta: "Avaliação da progressão da microbiota vaginal no período de transição em vacas leiteiras, associada com infecções uterinas.".

\section{Parecer Consubstanciado da Comissão de Ética no Uso de Animais FMVZ/USP}

A Comissão de Ética no Uso de Animais da Faculdade de Medicina Veterinária e Zootecnia da Universidade de São Paulo, no cumprimento das suas atribuições, analisou e APROVOU a Alteração do cadastro (versão de 15/fevereiro/2018) da proposta acima referenciada.

Resumo apresentado pelo pesquisador: "A eficiência reprodutiva é um parâmetro de extrema importância para a indústria moderna de leite, influenciando diretamente o desempenho econômico global das fazendas leiteiras. Aproximadamente metade da população de vacas leiteiras após o parto apresentam doenças uterinas, causando alterações do útero e ovário podendo levar a infertilidade, aumentando a possibilidade de descarte, gerando grande prejuízo econômico aos produtores leiteiros. Com o intuito de minimizar tais doenças e seus prejuízos, este trabalho teve como objeto avaliar a progressão da microbiota encontrada nas vaginas de vacas leiteiras Holandesas, durante o período de transição e as diferenças na composição bacteriana e carga bacteriana total (CBT) associada a doenças uterinas e fertilidade. Para tal, foram coletados uma swabs vaginais em duplicata de 573 vacas holandesas de uma fazenda leiteira comercial, nos dias -7, 0, 3 e 7 dias relativos ao parto. 0 presente estudo foi dividido em dois experimentos: No primeiro, foram selecionados swabs vaginais de 111 vacas. A microbiota foi caracterizada pelo sequenciamento do gene bacteriano 16S rRNA e a CBT foi determinada por PCR quantitativa em tempo real. No segundo experimento, Swabs vaginais de 573 vacas leiteiras, foram coletadas de cada vaca nos seguintes pontos: ?7, 0, 3, e 7 dias referentes ao parto, com o objetivo de monitorar o desenvolvimento da microbiota vaginal em um meio de cultura bacteriana cromogênico (Accumaster ${ }^{\circledR}$ ), para identificação do desenvolvimento de patógenos (Streptococcus spp., Staphylococcus spp. e bactérias Gram-negativas (Escherichia coli).".

Comentário da CEUA: "alteração de título aprovada.".

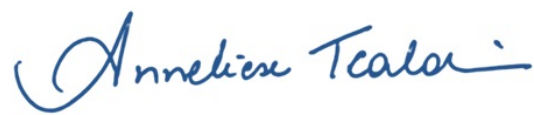

Profa. Dra. Anneliese de Souza Traldi Presidente da Comissão de Ética no Uso de Animais Faculdade de Medicina Veterinária e Zootecnia da Universidade de São Paulo

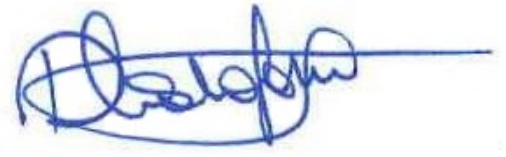

Roseli da Costa Gomes Secretária Executiva

Faculdade de Medicina Veterinária e Zootecnia da Universidade de São Paulo 


\section{FOLHA DE AVALIAÇÃO}

Nome: SANTIN, Thiago

Título: Avaliação da progressão da microbiota vaginal, no período de transição em vacas leiteiras, associada com infecções uterinas.

Tese apresentada ao Programa de PósGraduação em Reprodução Animal da Faculdade de Medicina Veterinária e Zootecnia da Universidade de São Paulo para a obtenção do título de Doutor em Ciências

Data:

Banca Examinadora

Prof.(a) Dr.(a):

Instituição: Julgamento:

Prof.(a) Dr.(a):

Instituição: Julgamento:

Prof.(a) Dr.(a):

Instituição: Julgamento: 


\section{DEDICATÓRIA}

Aos meus pais, irmãos, sobrinhos e cunhados Amo muito vocês! 


\section{AGRADECIMENTOS}

Agradeço a Deus. Por nunca me abandonares, por me amparares sempre que caí, por me dares força e ânimo através da minha fé em ti, que em momento algum enfraqueceu.

À minha mãe Neuza, pelo incentivo e apoio em todas as minhas decisões. Mãe esse título é seu.

Ao meu pai José Francisco, quantas saudades... tenho certeza que você olha por mim e está orgulhoso.

Aos meus irmãos queridos, Dú e Grá, obrigado pelo estímulo e por acreditarem em meus projetos, vocês são a minha base e inspiração.

Ao Professor Ed Hoffmann Madureira, por me ensinar a olhar o mundo de outra forma. Obrigado, pelos conselhos, conversas e pelas orientações no mestrado, doutorado e para a vida.

Ao Professor Rodrigo Bicalho e sua família, pela oportunidade de realizar um sonho de passar um ano na universidade de Cornell e realizar o meu experimento de doutorado.

Aos meus cunhados e sobrinhos que eu adoro tanto.

Aos Professores Rubens Paes de Arruda, Mario Binelli, André Furugen Cesar de Andrade e Carla Eneiva.

A todos os colegas de pós-graduação.

Aos funcionários, Clayton, Harumi, Zé Maria, João e Márcio. Aos funcionários do gado de leite, gado de corte, ovinoculura e suinocultura.

Ao Jimmy, Janes, Cindy, Boris e Hanna, pelo fiel companheirismo desde os tempos de faculdade. Meus dias são mais felizes com vocês. 
A todos os animais utilizados nos experimentos, a eles devo todo meu respeito e consideração.

A equipe da limpeza, pelos cafés e conversas matinais.

Ao Prof. Doutor Eduardo H. Birgel Júnior e Daniela Birgel.

A Melina Yasuoka pela amizade e pelo apoio nos momentos difíceis.

Peço desculpa, pois com certeza esqueci várias pessoas importantes.

Muito Obrigado! 
Se alguém está, pois, enraizado e fundado na fé, pode a tempestade elevar-se, podem os ventos soprar, pode a chuva cair a cântaros, não será abalado, nada ocorrerá, porque sobre a pedra o edifício foi fundado com sólida base. "Matheus 6 " 


\section{RESUMO}

\section{SANTIN, T. Avaliação da progressão da microbiota vaginal no período de transição em}

vacas leiteiras, associadas com infecções uterinas [Evaluation of progress of the microbiota found in the vaginas of dairy cows during the transition period: Associations with uterine diseases.]. TESE (Doutorado em Ciências) - Faculdade de Medicina Veterinária e Zootecnia, Universidade de São Paulo, Pirassununga, 2018.

A eficiência reprodutiva é um parâmetro de extrema importância para a indústria moderna de leite, influenciando diretamente o desempenho econômico global das fazendas leiteiras. Aproximadamente metade da população de vacas leiteiras após o parto apresentam doenças uterinas, causando alterações do útero e ovário podendo levar a infertilidade, aumentando a possibilidade de descarte, gerando grande prejuízo econômico aos produtores leiteiros. Com o intuito de minimizar tais doenças e seus prejuízos, este trabalho teve como objeto avaliar a progressão da microbiota encontrada nas vaginas de vacas leiteiras Holandesas, durante o período de transição e as diferenças na composição bacteriana e carga bacteriana total (CBT) associada a doenças uterinas e fertilidade. Para tal, foram coletados uma swabs vaginais em duplicata de 573 vacas holandesas de uma fazenda leiteira comercial, nos dias -7, 0, 3 e 7 dias relativos ao parto. O presente estudo foi dividido em dois experimentos: No primeiro, foram selecionados swabs vaginais de 111 vacas. A microbiota foi caracterizada pelo sequenciamento do gene bacteriano $16 \mathrm{~S}$ rRNA e a CBT foi determinada por PCR quantitativa em tempo real. Os fatores de risco relacionados com doença uterina foram Proteobacteria, Fusobacteria e Bacteroidetes. Vacas com retenção de placenta e vacas saudáveis apresentaram CBT similar no dia do parto, mas no D7, pós-parto, as vacas com a placenta retida demonstraram uma CBT significativamente maior, principalmente pela presença de grande quantidade de Fusobacteria e Bacteroidetes. Vacas diagnosticadas com metrite tiveram carga significativamente maior de Proteobactérias no D-7 e no D0 e maiores cargas estimadas de Fusobacteria no D3 e D7. Além disso, a carga de Bacteroidetes no D7 pós-parto foi maior para vacas diagnosticadas com endometrite aos 35 dias pós parto. Vacas que apresentaram febre no pós-parto, primíparas e que pariram gêmeos, também apresentaram maiores cargas de Fusobacteria e Bacteroidetes. Isso sugere que a composição da microbiota e 
CBT estão associados à conhecidos fatores de risco para doenças uterina e falhas reprodutivas no periparto aumentando o risco de doenças uterinas e falhas reprodutivas incluindo número de partos, distocia e retenção de placenta. No segundo experimento, Swabs vaginais de 573 vacas leiteiras, foram coletadas de cada vaca nos seguintes pontos: $-7,0,3$, e 7 dias referentes ao parto, com o objetivo de monitorar o desenvolvimento da microbiota vaginal em um meio de cultura bacteriana cromogênico (Accumaster®), para identificação do desenvolvimento de patógenos (Streptococcus spp., Staphylococcus spp. e bactérias Gram-negativas (Escherichia coli). Houve diferença no crescimento bacteriano para Sthaphyloccus spp em todos os dias relativos ao parto, para E.coli no D-7 e D7 e $(\mathrm{p}<0,05)$. A quantidade de animais com crescimento bacteriano para Sthaphyloccus spp e E.coli aumentou no parto e pós parto Foram fatores de risco para metrite a cetose $(\mathrm{p}<0,001)$, parto gemelar $(\mathrm{p}<0,05)$, retenção de placenta e parto na maternidade $(\mathrm{p}<0,001)$. Varios fatores de risco ligados a doenças e doenças uterinas foram significativamente diferentes para as vacas que apresentaram crescimento bacteriano para E.coli no pós parto.

Palavras chave: Afecções puerperais. Desempenho reprodutivo. Bactérias. Período de transição. Vacas leiteiras. 


\section{ABSTRACT}

\section{SANTIN, T. Evaluation of progress of the microbiota found in the vaginas of dairy cows}

during the transition period: Associations with uterine diseases. [Avaliação da progressão da microbiota vaginal encontrada no período de transição em vacas leiteiras, associados com infecções uterinas]. 2018. Tese (Doutorado em Ciências) - Faculdade de Medicina Veterinária e Zootecnia, Universidade de São Paulo, Pirassununga, 2018.

Reproductive efficiency is an extremely important parameter for the modern dairy industry, affecting the overall economic performance of dairy farms. Approximately half of the cows after childbirth present uterine diseases, causing changes in the uterus and ovary, leading to infertility, increasing the possibility of discarding, causing great economic harm to dairy farmers. The objective of this work was to evaluate the microbiota found in Holstein dairy cows during the transition period and the differences in bacterial composition and total bacterial load (CBT) associated with diseases and fertility. The present study was divided into two experiments: first, vaginal swabs from 111 Dutch cows from a commercial dairy farm were collected on days 7, 0,3 and 7 days of delivery. The microbiota was characterized by the sequencing of the bacterial $16 \mathrm{~S}$ rRNA gene and the CBT was determined by quantitative realtime PCR. The risk factors related to uterine disease were Proteobacteria, Fusobacteria and Bacteroidetes. Cows with retained placenta and healthy cows presented similar CBT on the day of calving, but in D7, postpartum cows with retained placenta demonstrated a significantly higher CBT, mainly due to the presence of large amounts of Fusobacteria and Bacteroidetes. Cows diagnosed with metritis had significantly higher burden of D-7 and D0 Proteobacteria and higher estimated Fusobacteria loads on D3 and D7. In addition, Bacteroidetes load in postpartum D7 was higher for cows diagnosed with endometritis at 35 days postpartum. Cows that presented postpartum fever, primiparous and who gave birth twins, also presented higher loads of Fusobacteria and Bacteroidetes. This suggests that the composition of the microbiota and CBT are associated with known risk factors for uterine diseases and peripartum reproductive failures, increasing the risk of uterine diseases and reproductive failures including number of deliveries, dystocia and retained placenta. In the second experiment, vaginal swabs from 573 dairy cows were collected from each cow at the following points: $-7,0,3$, and 7 days of delivery, with the objective of monitoring the development of the vaginal microbiota in a chromogenic culture medium (Accumaster@) to identify the development of pathogens (Streptococcus spp., Staphylococcus spp. And Gram- 
negative bacteria). (E. coli) on the D-7 and D7, and on the other hand, the presence of E. coli in E. coli ( $\mathrm{p}<0.05)$. The number of animals with bacterial growth for Sthaphyloccus spp and E.coli increased at delivery and postpartum were risk factors for ketosis metritis ( $p<0.001)$, twin birth $(\mathrm{p}<0,05)$, placenta retention and childbirth in the maternity ward $(\mathrm{p}<0.001)$. Several risk factors related to uterine diseases and diseases were significantly different for cows that presented bacterial growth for E. coli in the postpartum period.

Keywords: Dairy cows. Bacteria. Puerperal disorders. Reproductive performance. Transition period. 
1 INTRODUÇÃO …………….............................................................................................. 15

2 OBJETIVOS ....................................................................................................................... 17

2.1 OBJETIVO ESTUDO 1 .............................................................................................................. 17

2.2 OBJETIVOS ESTUDO 2................................................................................................................. 17

3 HIPÓTESE ........................................................................................................................... 17

3.1 HIPÓTESE ESTUDO 1 .................................................................................................. 17

3.2 HIPÓTESE ESTUDO 2 .................................................................................................. 17

4 REVISÃO DE LITERATURA...................................................................................... 18

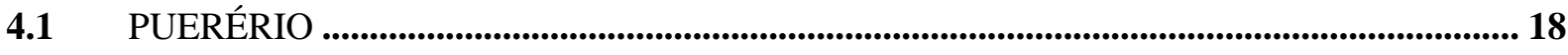

4.2 INVOLUÇÃO UTERINA................................................................................................................. 18

4.3 PERÍODO VOLUNTÁRIO DE ESPERA .................................................................................. 19

4.4 DEFINIÇÃO DE DOENÇAS UTERINAS................................................................................. 20

4.4.1 Definição de metrite ........................................................................................................................... 20

4.4.2 Definição de endometrite ........................................................................................................... 21

4.4.3 Endometrite clínica ........................................................................................................................ 22

4.4.4 Definição de endometrite subclínica ....................................................................................... 24

4.4.5 Definição de piometra .................................................................................................................... 24

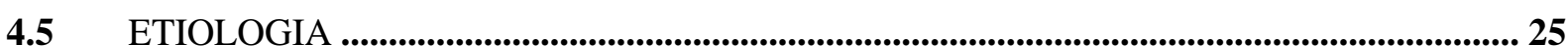

4.6 TRIÂNGULO EPIDEMIOLÓGICO............................................................................................... 26

4.7 FATORES DE RISCO ..................................................................................................... 30

4.7.1 Fatores associados ao animal..................................................................................................... 31

4.8 DIAGNÓSTICO..................................................................................................................... 31

5 MATERIAL E MÉTODOS ...................................................................................... 34

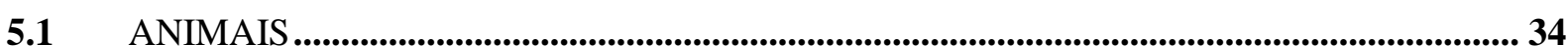

5.2 DELINEAMENTO EXPERIMENTAL ...................................................................................... 35

5.2.1 ESTUDO 1 .................................................................................................................. 37

5.2.2 ESTUDO 2 ............................................................................................................................... 41

5.3 ANÁLISE ESTATÍSTICA.............................................................................................................. 42

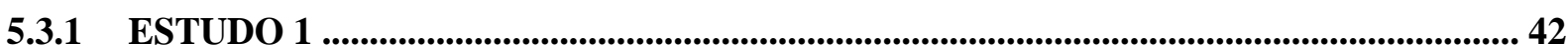

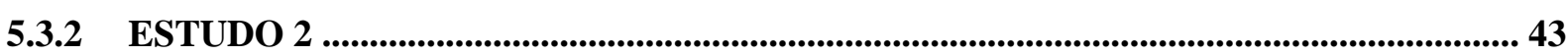

6.1 RESULTADOS E DISCUSSÃO ESTUDO 1 ............................................................................. 43

6.2 RESULTADOS E DISCUSSÃO ESTUDO 2 ........................................................................ 51

7.CONCLUSÕES .............................................................................................................................. 55

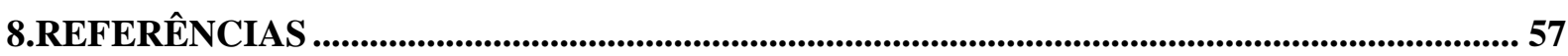




\section{INTRODUÇÃO}

A indústria de laticínios mundial evoluiu com o desenvolvimento e implantação da seleção genética do gado leiteiro, e também pelas melhorias nas instalações, produção, aspectos nutricionais e de gestão. Essas estratégias refletiram melhorias na produtividade animal e eficiência nas fazendas leiteiras. Entretanto, a tendência histórica para a fertilidade de vacas leiteiras em lactação seguiu um caminho oposto, devido a uma insignificativa seleção genética para características reprodutivas e de saúde animal, que refletiu em um declínio dos resultados das taxas reprodutivas (LUCY et al., 2001; NORMAN et al., 2009). Além disso, vacas leiteiras vivenciam período de transição, período, este, compreendido entre as últimas três semanas pré-parto e as três primeiras semanas de lactação (GRUMMER, 1995). Tal fase do ciclo produtivo é caracterizada por inúmeras alterações metabólicas e hormonais, visando o estabelecimento da produção leiteira (DRACKLEY, 1999). A maioria dos problemas de saúde, dentro do ciclo produtivo de uma vaca leiteira, ocorre durante este período de adaptação. A regulação e coordenação, principalmente do metabolismo de lipídios no fígado (alterações metabólicas), hormonais, imunológicas e de estresse oxidativo, ocorridas durante esse período, refletem diretamente na saúde, na produção e na fertilidade dos rebanhos (KIMURA et al., 2002; HATAMOTO, 2004; AGARWAL et al., 2012). A eficiência reprodutiva é um parâmetro de extrema importância para a indústria leiteira moderna, afetando o desempenho econômico global das fazendas. Dentre alguns fatores relacionados com o declínio no desempenho reprodutivo, podem-se citar os aspectos fisiológicos da vaca, saúde, manejo reprodutivo e animal. O melhor entendimento e intervenções nestas áreas são esperados para incrementar as taxas de prenhez e melhorar a fertilidade dos rebanhos (LUCY et al., 2001; ROYAL et al., 2008). Após o parto, a recuperação normal do trato reprodutivo é essencial para um desempenho produtivo satisfatório, pois durante o parto, a abertura das barreiras anatômicas, constituídas pela vulva, vagina e cérvice, possibilita a invasão do útero por bactérias ambientais, presentes nas fezes e na pele dos animais, aliados a alterações nos mecanismos de defesa em vacas imunossuprimidas, que contribuem para a instalação e persistência de bactérias patogênicas, favorecendo o estabelecimento de doenças, podendo resultar a subfertilidade (SHELDON E DOBSON, 2004; FÖLDI et al. 2006; SHELDON, 2007; SHELDON ET AL. 2008, 2009). Doenças uterinas no pós-parto (metrite, endometrite e piometra) são importantes, por razões 
econômicas e de bem-estar animal, pois os animais acometidos apresentam desconforto, maior chance de descarte do rebanho e desempenho reprodutivo prejudicado. Atualmente, aproximadamente 50\% das vacas de alta lactação, apresentam doenças uterinas após o parto, causando alterações no útero e ovários, podendo levar à infertilidade, aumentando assim a possibilidade de descarte, gerando grande prejuízo econômico aos produtores leiteiros (SHELDON et al., 2009). Nos Estados Unidos da América, a metrite afeta $10 \%$ a $20 \%$ de vacas, podendo chegar a 40\% (SHELDON et al., 2008), É possível calcular as perdas econômicas causadas pelas metrites, devido à diminuição na produção de leite, atraso na concepção, tratamento e descarte. Um animal afetado por metrite leva a um prejuízo de $\$ 380$. Se for considerada uma incidência média de 20\%, em 8.5 milhões de vacas leiteiras nos EUA, os prejuízos causados, somente pelas metrites, são de \$650 milhões (DRILLICH et al., 2001; OVERTON; FETROW, 2008). Outra doença uterina importante para a redução da fertilidade é a endometrite, (DUBUC et al., 2011), a incidência dessa doença nos rebanhos leiteiros é de aproximadamente 28\%, variando de 5,3\% a 52,6\% (DUBUC et al., 2010; LEBLANC et al., 2011; CHEONG et al., 2012). Observou-se em estudos baseados em meios de cultura para o desenvolvimento de bactérias, que Escherichia coli (E.coli), Streptococcus spp., Trueperella pyogenes (T. pyogeneses), Fusobacterium necrophorum e Bacteroides spp., Prevotella melaninogenica, anteriormente Bacteroides melaninogenicus) foram agentes comumente associados com metrite, endometrite e piometra (SHELDON et al., 2008). O entendimento da identificação e progressão das bactérias no puerpério e dos mecanismos pelos quais as bactérias afetam a imunidade uterina do hospedeiro e o comprometimento do trato reprodutivo, são fundamentais para desenvolver terapias capazes de reduzir os efeitos deletérios das doenças uterinas. 


\section{OBJETIVO}

\subsection{OBJETIVO ESTUDO 1}

O objetivo do estudo1 foi avaliar a microbiota vaginal de vacas leiteiras Holandesas, durante o período de transição e descrever as diferenças na composição bacteriana pelo sequenciamento do gene $16 \mathrm{~S}$ e carga bacteriana total (CBT), associadas à doença uterina e fertilidade.

\subsection{OBJETIVO ESTUDO 2}

O objetivo do estudo 2 foi monitorar o desenvolvimento da microbiota vaginal no puerpério e avaliar o uso de um meio seletivo cromogênico, para identificação de patógenos (Streptococcus spp., Staphylococcus spp. e bactérias Gram-negativas).

\section{HIPÓTESE}

\subsection{HIPÓTESE ESTUDO 1}

Vacas saudáveis ou com metrite diferem quanto à composição da microbiota vaginal.

\subsection{HIPÓTESE ESTUDO 2}

O uso de meios de cultura cromogênicos permite a identificação de patógenos associados com a metrite. 


\section{REVISÃO DE LITERATURA}

\subsection{Puerpério.}

Puerpério é o período compreendido entre o parto e o restabelecimento das funções normais do útero e ovários, para que a fêmea possa ter uma nova gestação. Nas fêmeas bovinas (poliéstricas anuais), é importante que o puerpério se desenrole de forma normal ou fisiológica, para assim poder iniciar uma nova gestação o mais rápido possível. Logo, o prolongamento desse período, denominado de puerpério patológico, pode provocar um forte impacto negativo no desempenho reprodutivo do animal e na lucratividade da fazenda (NOAKES, PARKINSON \& ENGLAND, 2001).

O puerpério fisiológico pode ser subdividido em três períodos distintos:(EMERICK et al, 2009; LEWIS, 1997): (1) período puerperal propriamente dito, que inicia-se após liberação fetal e continua até que a hipófise adquira a capacidade de resposta ao hormônio liberador de gonadotrofinas $(\mathrm{GnRH})$ (entre o sétimo e o $14^{\circ}$ dias pós-parto); (2) período intermediário que se inicia com o aumento da sensibilidade da hipófise perante os estímulos do GnRH, perdurando até a primeira ovulação. É nesta fase que a idade, estado nutricional, presença de eutocia ou distocia, retenção de placenta e infecções puerperais podem interferir e aumentar o intervalo parição-primeira ovulação; (3) período pós-ovulatório o qual se inicia após a primeira ovulação até completa involução uterina.

Segundo Sheldon et al, (2008) os processos necessários para que se estabeleça nova gestação são a involução uterina, a regeneração do endométrio, a eliminação da contaminação bacteriana e o reinício da atividade cíclica ováriana

\subsection{Involução uterina.}

Após o parto, o útero das fêmeas bovinas, se apresenta com volume significativamente aumentado, apresentando aproximadamente um metro e com peso a variar entre oito e treze quilogramas (LESLIE, 1983). A involução desse órgão envolve a simultaneidade de vários processos: necrose e desprendimento das carúnculas uterinas, a diminuição do tamanho do útero e a reparação do endométrio (KIRAKOFE, 1980). Com o estímulo provocado pela expulsão do feto e das membranas fetais, o útero inicia o processo de involução, com a 
finalidade de recuperar o seu tamanho normal (BENCHARIF et al, 2000; HAFEZ \& HAFEZ, 2004; SHELDON et al, 2008). Alterações mais significativas na diminuição do tamanho anatômico do útero ocorrem durante os primeiros quatro dias (NOAKES, PARKINSON \& ENGLAND, 2001), pela ação das contrações peristálticas provocadas pela grande quantidade de prostaglandina e pela vasoconstrição (KIRAKOFE, 1980). Do quarto ao nono dia, torna-se mais lenta, pelo fato de que neste período o útero permanece praticamente inerte, pois não responde aos estímulos hormonais responsáveis pela contratilidade; a partir do décimo, e até ao $14^{\circ}$ dia, volta a verificar-se um aumento na intensidade da involução (Kozicki,1998).

$\mathrm{O}$ útero passa de até $13 \mathrm{~kg}$, no momento do parto, para um $\mathrm{kg}$ às três semanas pósparto. (SHELDON et al, 2008). Juntamente com a involução uterina, inicia-se o processo de expulsão do lóquia, que é um líquido constituído por fragmentos de membranas fetais e uterinos, bactérias e células leucocitárias e é produzido nos primeiros dias após o parto (BENCHARIF et al, 2000; KOZICKI, 1998). Durante este processo de eliminação, ocorrem alterações da consistência e da coloração do lóquia, evoluindo de um líquido vermelhoacastanhado para um material viscoso e amarelo-esbranquiçado (SHELDON et al, 2006). Os principais fatores responsáveis por estes atrasos na involução são: raça, idade, e nutrição (KIRAKOFE, 1980). Outros fatores que têm um forte impacto no tempo necessário para a involução são a presença de infecções uterinas e/ou a retenção da placenta (RP) (KIRAKOFE, 1980). Segundo Sánchez, Sobrinho \& Gonçalves (1999), vacas que apresentaram metrite puerperal apresentam um tempo maior para a involução dos cornos uterinos, quando comparadas com vacas saudáveis.

\subsection{Período voluntário de espera.}

Período voluntário de espera (PVE) é o tempo aguardado para inseminar a vaca após o parto e varia de 45 a 60 dias (ROCHA E CARVALHEIRA, 2002). Dependendo da raça utilizada e da decisão do produtor esses intervalos podem ser mais curtos (30 dias) ou mais longos (90 dias) (DEJARNETTE, 2007). O retorno econômico é maior quando o período de serviço (intervalo do parto à nova gestação) é de 105 dias para primíparas e 63 dias para pluríparas, em rebanhos de alta produção (DE VRIES, 2007). Outros fatores como escore de condição corporal do animal, época do ano na qual ocorre o parto, média de produção leiteira da vaca e custo da inseminação, devido à baixa taxa de fertilidade, na primeira inseminação, podem 
influenciar na decisão dos produtores quanto à duração do PVE (DEJARNETTE, 2007; DE VRIES, 2007).

\subsection{Definição das doenças uterinas.}

Os termos "infecção uterina" ou "doença uterina" são considerados generalistas, pois os critérios utilizados para diagnosticar e classificar essas doenças são muito variados. Mais de 500 artigos sobre doenças uterinas foram publicados nos últimos 40 anos, demonstrando a importância dessa área na medicina veterinária (Pub med). Entretanto, frequentemente, a definição ou caracterização dessas doenças não são precisas, não foram validades e variam em muitos grupos de pesquisa, dificultando a avaliação do desempenho reprodutivo e eficácia dos tratamentos (GILBERT 1992). Além disso, não são descritos os critérios adotados para o diagnóstico, o que dificulta a comparação e a interpretação dos dados entre esses trabalhos (GAUTAM et al., 2010). Durante o 15th International Congress on Animal Reproduction,Gilbert 2004 sugeriu que pesquisadores da área, criassem definições claras e práticas. Sheldon et al (2006), escreveram um artigo após essa reunião, para criar uma padronização da nomenclatura das doenças uterinas, a fim de que as mesmas fossem utilizadas no meio acadêmico (Tabela 1).

\subsubsection{Definição de Metrite}

A metrite distingue-se da endometrite pela profundidade histológica que a inflamação atinge (LeBlANC, 2008). É definida como inflamação severa das camadas do útero (mucosa endometrial, submucosa e muscular) (BONDURANT, 1999). Quando a serosa é atingida, a metrite é denominada de perimetrite e quando chega a atingir o ligamento largo é definida como parametrite (HILLMAN \& GILBERT, 2008; SHELDON et al, 2006). Em muitos casos, o termo metrite é usado como uma definição generalista, para descrever uma ampla gama de intervalos do pós-parto e condições patológicas, incluindo infecções relacionadas com o endométrio e referentes a todas as camadas do útero (HILLMAN \& GILBERT, 2008; LEBLANC, 2008). Sheldon et al (2006), propuseram como definição clínica, para um caso de metrite puerperal, com um animal, que apresente um aumento anormal do útero, com corrimento uterino, vermelho-acastanhado, fétido e aquoso, durante os primeiros 21 dias após o parto. Entretanto, quando ocorre na primeira semana após o parto, é denominada de metrite 
puerperal, e está sempre associada a sinais sistêmicos de doença como diminuição na produção de leite, apatia, inapetência, desidratação, anorexia, elevada frequência cardíaca além de outros sinais de toxemia e hipertermia (TR> 39, $5^{\circ} \mathrm{C}$ ). A metrite puerperal geralmente está associada à retenção de placenta, distocias, natimortos ou gestações gemelares, iniciandose na primeira semana. podendo persistir até o final da segunda semana após o parto. Aproximadamente $50 \%$ das vacas com metrite não são diagnosticada com febre (BENZAQUEN et al., 2007; MARTINEZ et al., 2012; LIMA et al., 2014). Em animais que não apresentam febre, mas possuem um útero anormalmente aumentado e corrimento uterino purulento (conteúdo com mais de 50\% de pus), detectado na vagina durante os primeiros 21 dias do pp ( geralmente entre 14 e 21 dias), devem ser considerados como casos de metrite clínica (SHELDON et al, 2006).

Sheldon et al (2009) propuseram ainda que as metrites fossemclassificadas segundo os sinais clínicos demonstrados e o grau de severidade. Essa classificação consiste em três graus de metrite:

$\Rightarrow$ Grau 1 ou metrite clínica - Animais com útero aumentado, corrimento uterino purulento, sem sinais sistêmicos de doença;

$\Rightarrow$ Grau 2 ou metrite puerperal - Animais com útero aumentado, corrimento aquoso e fétido, associado com sinais sistêmicos (diminuição na produção de leite, apatia e sinais de toxemia) e hipertermia $\left(\mathrm{TR}>39,5^{\circ} \mathrm{C}\right)$;

$\Rightarrow$ Grau 3 ou metrite puerperal tóxica/séptica - Animais que, para além dos sinais descritos para o grau dois, podem ainda apresentar outra sintomatologia referente à toxemia como a inapetência, extremidades frias, depressão e/ou colapso.

\subsubsection{Definição de Endometrite}

Histologicamente, a endometrite é definida como uma inflamação superficial do endométrio, que é caracterizada por uma leve descamação da superfície epitelial, infiltração de células inflamatórias, congestão vascular, edema e acúmulo de várias formas de linfócitos, nas camadas superficiais do endométrio e pode ser considerada como o estágio crônico da doença (BONDURANT, 1999). Do ponto de vista clínico, a definição está dividida em duas formas, a clínica e a subclínica ou citológica. 


\subsubsection{Endometrite clínica}

A endometrite clínica é caracterizada pela presença de corrimento uterino purulento (> $50 \%$ pus), ou mucopurulento (50\% pus e 50\% muco), no interior da vagina (FIGURA 1), após 21 dias ou mais do parto (SHELDON et al, 2006). Como a metrite puerperal, a endometrite pode ser desencadeada pelos mesmos agentes etiológicos e os mesmos fatores de risco (NOAKES,PARKINSON \& ENGLAND, 2001; SHELDON et al, 2009). Entretanto, diferentemente da metrite puerperal, a endometrite não apresenta sinais sistêmicos, como hipertermia ou depressão da atitude do animal (DRILLICH, 2006). A principal consequência está relacionada com o impacto negativo que ela causa no desempenho reprodutivo (NOAKES, PARKINSON \& ENGLAND, 2001), levando a um aumento no intervalo entre o parto e o primeiro serviço, aumentando os dias abertos, diminuindo o número de animais gestantes ao primeiro serviço, fazendo com que haja necessidade de um maior número de inseminações para as fêmeas ficarem gestantes, aumentando assim a probabilidade de descarte por infertilidade. (LEBLANC et al, 2002).

Segundo LEBLANC et al., (2002) alguns critérios para diagnosticar endometrites, em vacas leiteiras, foram validados 21 dias após o parto, porém não são precisos, pois nesse período pode-se incluir uma proporção maior de animais positivos que se recuperam espontaneamente. Ela foi definida como presença de muco purulento vaginal, ou diâmetro cervical $>7,5 \mathrm{~cm}$, pela palpação transretal, 21 dias ou mais após o parto, ou a presença de um material mucupurulento na vagina, 26 dias após o parto. Utilizando esta classificação para endometrite, as diferenças temporais provavelmente refletem o progresso da involução uterina e da defesa imunológica. Além disso, o lóquio possui variações na aparência normal. Da mesma forma, não é confiável utilizar somente a involução uterina retardada como parâmetro, pois o útero aumentado pode ter causas multifatoriais, como danos físicos, ou variações associadas com a raça, idade, ou nutrição, em vez de infecção bacteriana, enquanto um pequeno aumento no diâmetro das artérias uterinas e cornos uterinos podem ser de difícil detecção, em casos leves de endometrite.

Assim, a palpação do útero, para avaliar seu tamanho, não tem boa precisão no diagnóstico da endometrite (MILLER et al., 1980; LE BLANC et al., 2002)

Apesar da definição de endometrite clínica ter uma boa aceitação por clínicos e pesquisadores, um estudo recente mostrou que vacas podem apresentar descarga purulenta 
vaginal (DPV), sem apresentar inflamação endometrial, podendo ser proveniente de outras estruturas (DUBUC et al., 2010).

Endometritis scoring scheme
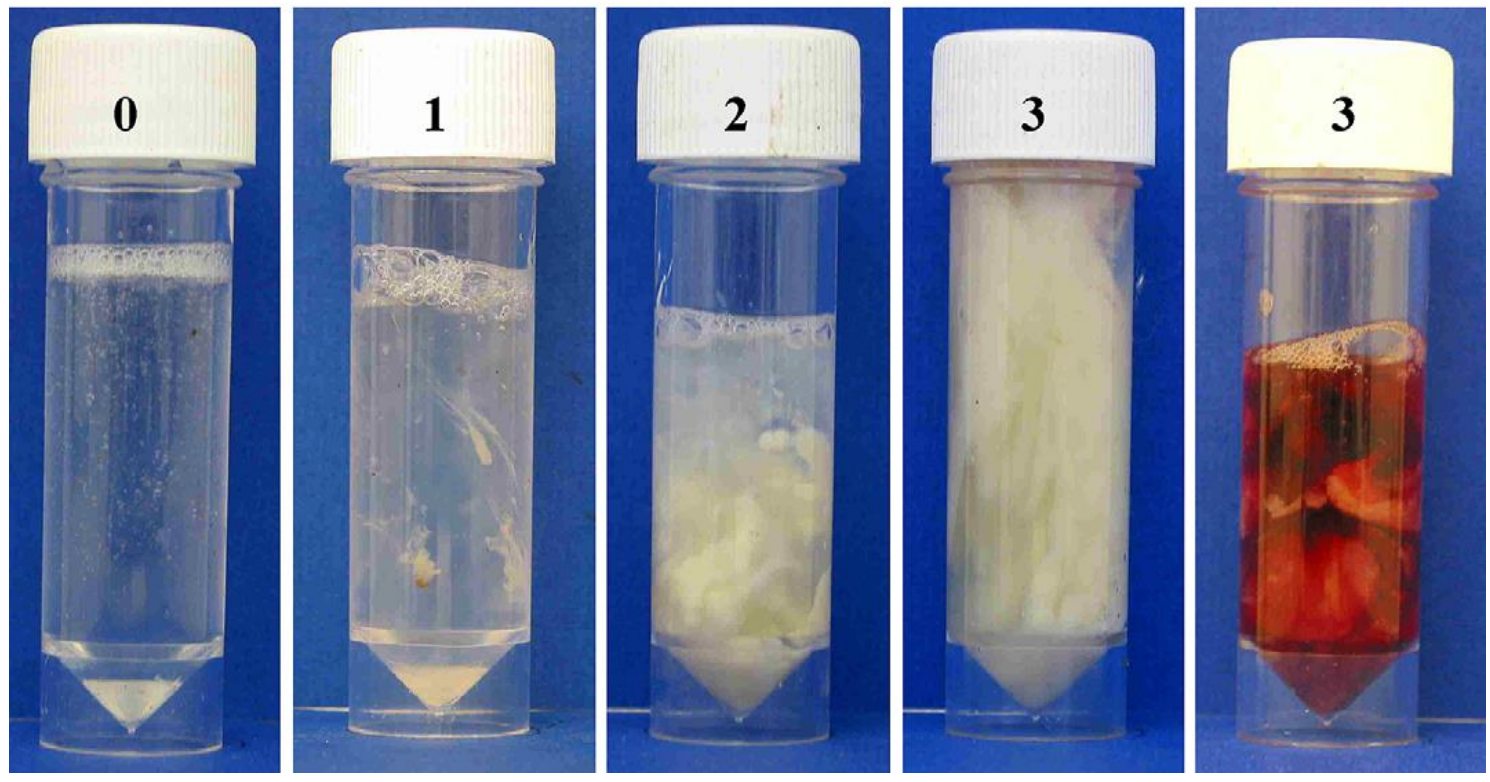

Figura-1. Classificação do muco vaginal: Escore $0=$ muco transparente ou translúcido; escore $1=$ muco contendo flocos de pús branco; escore $2=$ descarga contendo $\leq 50 \%$ de pús; e escore $3=$ descarga contendo material purulento $>50 \%$, geralmente de cor branca ou amarela, mas ocasionalmente sanguínea. (WILIANS et al., 2006) 


\subsubsection{Definição de endometrite subclínica}

Endometrite subclínica é definida como a inflamação do endométrio, determinada por citologia, de amostras colhidas por lavagem do lúmen uterino, ou por cytobrush endometrial (GILBERT et al., 2005). A endometrite sub-clínica, difere da endometrite clínica, pois ocorre ausência de corrimento cérvico-uterino, com propriedades patogênicas (FÖLDI et al, 2006). Pode afetar entre 35-50\% dos animais entre os dias 35-50 pp., e provocar um forte impacto no desempenho reprodutivo com diminuição da fertilidade, e aumento dos dias em aberto (LEBLANC, 2008). O diagnóstico da endometrite subclínica é realizado pela quantificação da porcentagem de neutrófilos presentes em uma amostra de muco ou fluído uterino, por lavagem do lúmen uterino (Figs. 1B e 2B), com aproximadamente $20 \mathrm{ml}$ de solução salina estéril ou por cytbrush. (GILBERT et al., 2004; KASIMANICKAM et al., 2004). O diagnóstico é positivo quando é encontrada a presença de $>18 \%$ de neutrófilos, em amostras de citologia uterina, coletadas entre 20-33 dias após o parto, ou >10\% de neutrófilos 7 dias após o parto, na ausência de endometrite clínica (GILBERT et al., 2004; HILLMAN, R. \& GILBERT, R. O. 2008). No presente estudo, as definições de infecções uterinas sâo baseadas no período de ocorrência e nos sinais clínicos (Tab. 1), segundo o modelo proposto por Sheldon et al., (2006).

\subsubsection{Definição de piometra}

Piometra é caracterizada pelo acúmulo de material purulento no lúmen uterino, distensão do útero, na presença de um corpo lúteo ativo no ovário e cérvice fechada. Entretanto, o lúmen da cérvice nem sempre é completamente fechado, podendo ocorrer descarga de pus na vagina, proveniente do útero (Sheldon et al., 2006). No exame ultrassonográfico, a piometra é caracterizada por uma mistura de fluidos de ecogênecidade heterogênea no lúmen uterino, distensão do útero e presença de corpo lúteo persistente no ovário (SHELDON et al., 2006) Sua prevalência varia de 11 à > 70\% em alguns rebanhos (KASIMANICKAM et al., 2004; GILBERT et al, 2005; HAMMON et al., 2006; BARLUND et al., 2008; GALVÃO et al., 2009a; CHEONG et al., 2011). 
Tabela 1. Tipos de infecção uterina na vaca, época de ocorrência e sinais clínicos.

\begin{tabular}{|c|c|c|}
\hline Tipo de infecção uterina & Período ocorrência & Sinais clínicos \\
\hline Metrite puerperal & $\begin{array}{l}\text { Tem início na } \\
\text { primeira semana e } \\
\text { pode persistir até o } \\
\text { final da segunda } \\
\text { semana pós-parto. }\end{array}$ & $\begin{array}{l}\text { Os sintomas estão associados à retenção de placenta, } \\
\text { distocias, abortos ou partos gemelares. Verificam-se } \\
\text { secreção vaginal sanguinopurulenta com odor fétido e } \\
\text { sinais sistêmicos, como febre (temperatura retal }>39,5^{\circ} \mathrm{C} \text { ), } \\
\text { desidratação, anorexia, depressão e queda na produção de leite. }\end{array}$ \\
\hline Metrite clínica & $\begin{array}{l}\text { Entre } 14 \text { e } 21 \text { dias } \\
\text { pós-parto. }\end{array}$ & $\begin{array}{l}\text { Aumento de volume anormal do útero, presença de secreção } \\
\text { purulenta ( }>50 \% \text { de pus) e ausência de sinais sistêmicos. }\end{array}$ \\
\hline Endometrite clínica & $\begin{array}{l}\text { Pode ocorrer além de } \\
21 \text { dias pós-parto. }\end{array}$ & $\begin{array}{l}\text { Secreção vaginal purulenta além de } 21 \text { dias após o parto, } \\
\text { ou presença de conteúdo mucopurulento na vagina além de } \\
26 \text { dias pós-parto. }\end{array}$ \\
\hline Endometrite subclínica & $\begin{array}{l}\text { Após o período } \\
\text { voluntário de espera. }\end{array}$ & $\begin{array}{l}\text { Somente é identificada por meio da contagem de } \\
\text { neutrófilos presentes no conteúdo uterino: mais de } 18 \% \text { de } \\
\text { neutrófilos em relação às células epiteliais do endométrio, } \\
\text { entre } 21 \text { e } 33 \text { dias pós-parto, ou mais de } 10 \% \text { entre } 34 \text { e } 47 \\
\text { dias pós-parto. }\end{array}$ \\
\hline Piometra & $\begin{array}{l}\text { Em qualquer fase do } \\
\text { puerpério. }\end{array}$ & $\begin{array}{l}\text { Retenção de conteúdo purulento ou mucopurulento no } \\
\text { útero e cérvix fechada, mais comum em animais com rápido } \\
\text { retorno da ciclicidade pós-parto (presença de corpo lúteo). }\end{array}$ \\
\hline
\end{tabular}

\subsection{ETIOLOGIA}

A etiologia da metrite é multifatorial. Admite-se que esta ocorra pela interrupção ou atraso na involução uterina, juntamente com a infecção do útero. (RADOSTITS et al., 2002). A função uterina é frequentemente comprometida por contaminação do lúmen uterino, a grande maioria das vacas apresenta bactérias no lúmen uterino; nas primeiras duas semanas após o parto (ELLITOT et al., 1968; BEKANA; KINDAL, 1996). Entretanto, algumas vacas conseguem eliminar essas bactérias durante as 5 primeiras semanas pós parto, porém as bactérias patogênicas podem persistir, causando doenças uterinas, que são uma das principais causas de infertilidade em vacas leiteiras (SHELDON et al., 2004). A persistência de bactérias patogênicas no útero causa inflamação, lesões histológicas, aumenta a taxa de morte embrionária e atrasa a involução uterina. (SEMAMBO et al., 1991; SHELDON et al., 2003). Em adição, os produtos das bactérias (LPS), ou a inflamação associada, suprimem a secreção hipofisária de LH, perturbando o desenvolvimento folicular, alterando o momento da ovulação, causando cistos e alterações no intervalo entre estros (SHELDON et al., 2002; OPSOMER et al., 2000).

Nesse contexto, as infecções uterinas aumentam o intervalo ao primeiro serviço, associado com baixa taxa de prenhez, aumentando o intervalo entre partos, número de 
serviços e o número de animais descartados por infertilidade. (LEBLANC et al., 2002; BORSBERRY; DOBSON, 1989; STUDER; MORROW, 1978; HUSZENICZA et al.,1999).

\subsection{TRIÂNGULO EPIDEMIOLÓGICO}

O triângulo epidemiológico, ou simplesmente tríade, é um tradicional modelo de estudo das causas e efeitos das doenças infectocontagiosas. Ele elucida a interação entre os fatores epidemiológicos, que contribuem para o acometimento de uma determinada doença: os agentes externos (o patógeno ou organismo causador da doença), a susceptibilidade dos hospedeiros e o ambiente de forma geral (MERRILL, 2013). O ambiente influencia o agente, o hospedeiro, e a via de transmissão do agente a partir de uma fonte para o hospedeiro. Metrite e endometrite são doenças complexas de caráter multifatorial, causadas por diversas bactérias. Nas últimas duas décadas, vários estudos contribuíram para o melhor entendimento dos fatores que influenciam o risco de acometimento dos animais. Devido a essa natureza multifatorial, é importante pensar no triângulo epidemiológico das doenças (STEVENS, 1960). Em vacas leiteiras no puerpério, encontra-se um hospedeiro susceptível, patógenos virulentos e ambiente favorável para o desenvolvimento desses microrganismos (MERRILL, 2013). A expressão dos sinais clínicos depende da interação entre esses três fatores (AZAWI, 2008). Começando pela vaca leiteira (o hospedeiro), que passa por uma mudança metabólica crítica durante o período de transição para a lactação (DRACKLEY, 1999). A ingestão de matéria seca é menor do que o necessário para a produção de leite, levando à condição de balanço energético negativo (ROCHE et al., 2009). Esse processo é resultado das transformações que ocorrem no final da gestação e início da lactação (KIMURA et al, 2006).

O período de transição engloba não somente um estado de balanço energético negativo, mas também outro fator muito importante, o desequilíbrio mineral e vitamínico (GOFF; HORST, 1997). Nesse período, ocorre também a transição da dieta com base em fibras, para uma dieta rica em concentrado. Além disso, próximo ao parto, a vaca tem uma redução de $20 \%$ de ingestão de matéria seca, no momento em que ocorre um aumento na exigência nutricional, para o desenvolvimento fetal e suporte nutricional, necessário para que as glândulas mamárias sintetizem colostro e leite (BELL, 1995; GOFF et al., 2002). Isto leva a uma diminuição acentuada nos minerais (cálcio e selênio), vitaminas (A e E) e glicose no puerpério, acarretando um aumento na mobilização de gordura corporal, na forma de ácidos graxos não esterificados (NEFA). A alta mobilização de triacilglicerol leva à excessiva 
absorção de NEFA pelo fígado; que por consequência, leva à oxidação incompleta destes ácidos graxos e acúmulo de corpos cetônicos, tais como beta-hidroxibutirato (BHBA) no sangue (VAZQUEZ-ANON et al., 1994).

Este estado negativo de ingestão de energia, vitamina e minerais leva a vaca à imunossupressão (KEHRLI; GOFF, 1989; GILBERT et al, 1993; CAI et al., 1994) e aumento da susceptibilidade a doenças, dentre essas, infecções uterinas (GALVÃO et al, 2012; MARTINEZ et al, 2012). O patógeno: durante e após o parto, a abertura das barreiras anatômicas constituídas pela vulva, vagina e cérvce, possibilita a invasão do útero por bactérias ambientais, presentes nas fezes e na pele dos animais. O útero das vacas é geralmente contaminado com uma variedade de bactérias, porém alguns animais conseguem debelar a infecção algumas semanas após o parto; portanto essa contaminação não está consistentemente associada à doença clínica. Infecção implica a adesão de organismos patogênicos na mucosa, colonização ou penetração do epitélio, e/ou liberação de toxinas bacterianas, que conduzem a instalação da doença no útero (HEUER; SCHUKKEN; DOBBELAAR, 1999). No período puerperal, uma grande variedade de bactérias Gramnegativas e Gram-positivas está presente, visto que o útero da vaca, após o parto, consegue manter o desenvolvimento de espécies bacterianas aeróbias, anaeróbias e anaeróbias facultativas (Smith \& Risco, 2002). As espécies bacterianas comumente isoladas no útero são os aeróbios Escherichia coli (E. coli), Trueperella pyogenes (T. pyogenes), anteriormente denominada de Arcanobacterium pyogenes (A.pyogenes), seguids de uma gama de bactérias anaeróbicas, tais como Fusobacterium necrophorum (F. necrophorum) e Prevotella melaninogenicus (P. melaninogenicus) e bactérias oportunistas, tais como Pseudomonas spp., Streptococcus spp., E Staphylococcus spp., que foram identificados em uma variedade de combinações, utilizando métodos convencionais de culturas bacterianas (SHELDON et al., 2002; WILLIAMS et al., 2005; SANTOS et al., 2010). Dentre estas, a E. coli e o T. pyogenes são as principais espécies isoladas do útero das vacas com metrite puerperal (HIRVONEN et al, 1999). Outras bactérias patogênicas, tais como, as Bacteroides spp., Ureaplasma spp., Staphylococcus spp., Helococcus spp., Prevotella melaninogenicus e Streptococcus spp., também têm sido associadas com doenças uterinas (AZAWI et al, 2008; MACHADO et al., 2012; LOCATELLI et al, 2013). Tradicionalmente, a E. coli está descrita como o principal microrganismo relacionado com a causa de infecção uterina e manifestação da doença pós parto (STUDER; MORROW, 1978; BONNETT et al., 1991; BICALHO et al., 2010; SHELDON et al, 2010). Sua penetração e colonização do endométrio uterino estão 
intimamente relacionadas com o desenvolvimento de infecção uterina por outros agentes bacterianos, como T. pyogenes e F. necrophorum (AZAWI, OMRAN \& HADAD, 2007).

O lóquia presente no útero após o parto propicia um meio ideal de crescimento e multiplicação da E. coli, resultando na liberação de endotoxinas, como lipopolissacarídeos (LPA), que favorecem o desenvolvimento de futuras infecções uterinas provocadas por $T$. pyogenes e outras bactérias Gram-negativas, principalmente se precedida de RP ou distocia (DOHMEN et al, 2000).

Vários trabalhos têm relatado que a E. coli é uma bactéria ambiental meramente oportunista, porque nenhum dos fatores de virulência avaliadas em um estudo estavam associados com a probabilidade de ocorrência de doenças uterinas (SILVA et al., 2009). Entretanto, estudos recentes caracterizaram importantes fatores de virulência, que permitem a E. coli se ligar e invadir o endométrio bovino. Essas descobertas trouxeram avanços significativos para compreender como essa bactéria tem um papel na patogenia da metrite e endometrite (BICALHO et., al., 2010; SHELDON et al., 2010). T. pyogeneses, é uma bactéria gram positiva, não formadora de esporos, (JOST; BILLINGTON, 2005), comumente encontrada no trato urogenital, gastrointestinal e vias respiratórias superiores de muitas espécies animais (CARTER et al., 2004) e está consistentemente associada à metrite e, especialmente, endometrite (STUDER; MORROW, 1978; WILLIAMS et al., 2005; BICALHO et al., 2012;. MACHADO et al., 2012.). Existe uma correlação positiva encontrada particularmente entre o $T$. pyogenes, Prevotella melaninogenicus e o $F$. necrophorum (DOHMEN et al, 1995).

A suposição mais aceita é que a ação sinérgica entre estas bactérias provoca o aparecimento e desenvolvimento de infecções, com maior grau de severidade (RISCO, YOUNGQUIST \& SHORE, 2007; SMITH \& RISCO, 2002). O F. necrophorum é esponsável pela produção de uma leucotoxina, que permite o desenvolvimento da $T$ pyogenes. A Prevotella melaninogenicus inibe a fagocitose, e o $T$. pyogenes produz um fator de crescimento essencial para a proliferação do F. necrophorum (SHELDON et al, 2009; SMITH \& RISCO, 2002). T. pyogenes está equipado com vários fatores de virulência que são importantes para o seu potencial patogênico. O seu principal fator de virulência, pyolysin (PLO), é uma potente citolisina, dependente de colesterol e está associada com o dano tecidual causado, (JOST E BILLINGTON, 2005; AMOS et al., 2014.). A T. pyogenes pode provocar uma resposta inflamatória celular no útero, mas o endométrio intacto está protegido contra os danos causados por PLO (MILLER et ai, 2007; AMOS et al, 2014.). Sugere-se que 
a T. pyogenes atua no útero no pós-parto como um agente patogênico oportunista, causando doença, uma vez que a camada epitelial é perdida após o parto, o que pode ter sido um resultado de infecção intrauterina anterior e/ou a um acontecimento traumático durante o parto, tal como distocia, parto gemelar e RP (DOHMEN et al., 2000; BICALHO et al., 2012). Por último temos o ambiente: Parece óbvio pensar que a falta de higiene no ambiente do parto possa ser um fator predisponente para o desenvolvimento bactérias e desenvolvimento de doenças intrauterinas. No entanto, nos estudos são apresentados dados conflitantes para apoiar a sua importância. A limpeza da região perineal, no momento do parto, foi associada com metrite (SCHUENEMANN et al., 2011). Quando se utiliza palha para cama, no momento do parto, houve menor incidência de metrite e endometrite subclínica, quando comparada a outro material (CHEONG et al., 2011.). Palha pode ser considerado um material de cama mais limpo, do que areia e maravalha por exemplo. Partos em pastos também foram associados com menor incidência de metrite. A pastagem também pode ser considerada como um ambiente menos contaminado com bactérias do que um curral (KANEENE E MILLER, 1995). No entanto, em outros estudos a falta de higiene não foi relacionada a doenças uterinas. POTTER et al. (2010) não observaram associação entre endometrite clínica e marcadores de higiene como escore de consistência fecal, escore de limpeza da vaca, desinfecção de equipamentos usados no parto e uso de luvas em partos assistidos. Outrossim, a microbiota uterina de vacas de duas fazendas higienicamente contrastantes não foi influenciada pelo estado de higiene ambiental (NOAKES et al., 1991). Segundo Cheong et al., (2011), o tipo de instalação foi associado à incidência de endometrite subclínica. Vacas pósparto, em galpões freestall, tiveram menor incidência de endometrite subclínica do que vacas abrigadas em composto Barn (CHEONG et al., 2011). Outro fator importante é o agrupamento e a dominância que atua no comportamento alimentar de vacas leiteiras no pós parto (SCHIRMANN et al, 2011.), entretanto reagrupamento das vacas pré-parto não foi significativamente importante para doenças uterinas (CHEONG et al, 2011.; SILVA et al., 2013). Markusfeld (1984) relatou que as vacas que pariram durante o verão têm maior probabilidade de ser afetadas por metrite. Estresse térmico também foi considerado fator predisponente para retenção de placenta (RP) e, consequentemente, metrite (DUBOIS; WILLIAMS, 1980). No entanto, muitos autoresnão relataram que a estação do ano é importante para a incidência de metrite e endometrite (DUBUC et al., 2010; PRUNNER et al., 2014). Possivelmente, devido aos avanços no manejo tenham minimizados os efeitos prejudiciais da estação do ano para a saúde uterina pós-parto (COLLIER et al., 2006). 


\subsection{FATORES DE RISCO}

Entre os fatores de risco associados à metrite puerperal encontram-se RP, afecções metabólicas (hipocalcemia e cetose), complicações no parto (natimortos, distocia, parto gemelar e abortos), número de lactações, idade, estação do ano, níveis elevados ou deficientes de condição corporal e ausência de pastoreio e higiene (FÖLDI et al, 2006; MALINOWSKI et al, 2010). Estes fatores de risco são problemas comuns observados com frequência nas fazendas leiteiras, tanto por produtores como por veterinários, o que facilita o aparecimento e desenvolvimento da infecção bacteriana, como também pode provocar um aumento da severidade da infecção já estabelecida (SMITH \& RISCO, 2002).

\subsubsection{Fatores associados ao animal}

Os bovinos leiteiros apresentam um maior risco de desenvolver metrite puerperal do que os bovinos de corte (FÖLDI et al, 2006). A idade é um fator importante para metrites. Em estudo realizado no Canadá, demontrou-se que que a incidência é mais alta nas vacas com mais de dez anos, elevada nos animais entre os sete e os dez anos e mais baixa entre os dois e quatro anos de idade (ERB \& MARTIN, 1980). No que diz respeito à associação da metrite puerperal com o número de lactações, Garcia et al (2004) concluíram que as vacas primíparas apresentam um maior risco de desenvolver metrite puerperal, quando comparadas com aquelas com maior número de lactações. Segundo os autores, a justificativa para este resultado deve-se ao fato dos animais apresentarem maior probabilidade de necessitarem assistência durante o parto e da ocorrência de RP.

\subsection{DIAGNÓSTICO}

A realização do exame ginecológico no pós-parto é uma das medidas recomendadas para a identificação das infecções uterinas, visando a rápida intervenção e consequentemente, o aumento da eficiência reprodutiva do rebanho (MARQUES JÚNIOR, 1993). Técnicas de diagnóstico como, vaginoscopia, ultrassonografia (avaliação da espessura do endométrio e 
fluido endometrial), histeroscopia e um dispositivo coletor de muco intravaginal, são comumente utilizadas nas fazendas leiteiras (Metricheck®, Simcro, Hamilton, New Zealand). (MCDOUGALL et al., 2007; BARLUND et al., 2008; MADOZ et al., 2010). Vaginoscopia e metricheck são ferramentas usadas para avaliar o muco vaginal e diagnosticar a inflamação do útero, tendo como vantagem, baixo custo, rapidez e facilidade do exame, além de serem obtidas informações adicionais, como volume, aspecto e odor da secreção cervicovaginal (SHELDON; DOBSON, 2004; WILLIAMS et al., 2005; GAUTAM et al., 2010).

No entanto, corrimento vaginal pode ser resultado de vaginite ou cervicite, erroneamente associadas à endometrite. Para determinar os falsos positivos e falsos negativos, é necessária a utilização da cultura bacteriana, para isolamento dos patógenos uterinos e a citologia para diagnosticar quadros de endometrite subclínica. As duas técnicas citadas anteriormente, também têm como aspecto positivo, a possibilidade de ser utilizadas como exames complementares, para detectar causas de subfertilidade em rebanhos, com problemas de repetição de estro sem causa aparente.

Os pontos negativos são o tempo para execução da técnica (cultura bacteriana e citologia) e o custo (cultura) A cultura bacteriana é um exame que não aumenta o grau de precisão do diagnóstico, pois normalmente a flora encontrada nestes exames é semelhante à encontrada nos animais em condições fisiológicas normais durante o puerpério (DOLEZEL et al, 2008), além de que a necessidade de realizar o tratamento leva a que este seja realizado antes da chegada dos resultados. A única razão que está indicada para a realização da cultura bacteriana e do teste de sensibilidade aos antibióticos é quando se está perante uma exploração com elevada prevalência de infecções uterinas, ou quando as vacas não respondem positivamente ao tratamento (RISCO, YOUNGQUIST \& SHORE, 2007). (WILLIAMS et al., 2005;).

A palpação vaginal consiste, em primeiro lugar, na limpeza da região vulvar com um papel ou toalha seca, seguindo-se a introdução da mão no interior da vagina com uma luva lubrificada, e o retirar do conteúdo do lóquio do interior do útero (SHELDON et al, 2008). Este exame de diagnóstico é considerado como uma técnica simples, rápida e que disponibiliza elevada informação sensorial ao permitir detectar possíveis lacerações vaginais (vaginite, cervicite necrótica) ou RP (HILLMAN \& GILBERT, 2008). Na metrite puerperal, o exame permite a remoção do interior da vagina de lóquio fétido e com coloração vermelho acastanhada, que é um sinal patognomônico da doença (RADOSTITS et al, 2002). No entanto, alguns autores referem que durante a realização da palpação vaginal, alguns animais 
demonstram um desconforto agudo à palpação (NOAKES, PARKINSON \& ENGLAND, 2001). Além disso, alguns autores também consideram que a realização da palpação vaginal pode aumentar o risco de provocar contaminação bacteriana. Entretanto Sheldon et al (2002) consideraram que a execução cuidadosa dessa técnica, não aumenta o risco de contaminação bacteriana, não afeta a involução dos cornos uterinos, nem aumenta a resposta das proteínas de fase aguda.

Segundo Barlund et al.(2008), avaliação ultra-sonográfica do volume de fluido uterino e espessura endometrial não foi um bom indicador do desempenho reprodutivo.A histeroscopia não é uma técnica prática no campo . Algumas dessas técnicas são subjetivas e podem sofrer variação entre observadores e a falta de treinamento pode levar a um diagnóstico errado, principalmente da endometrite clínica.

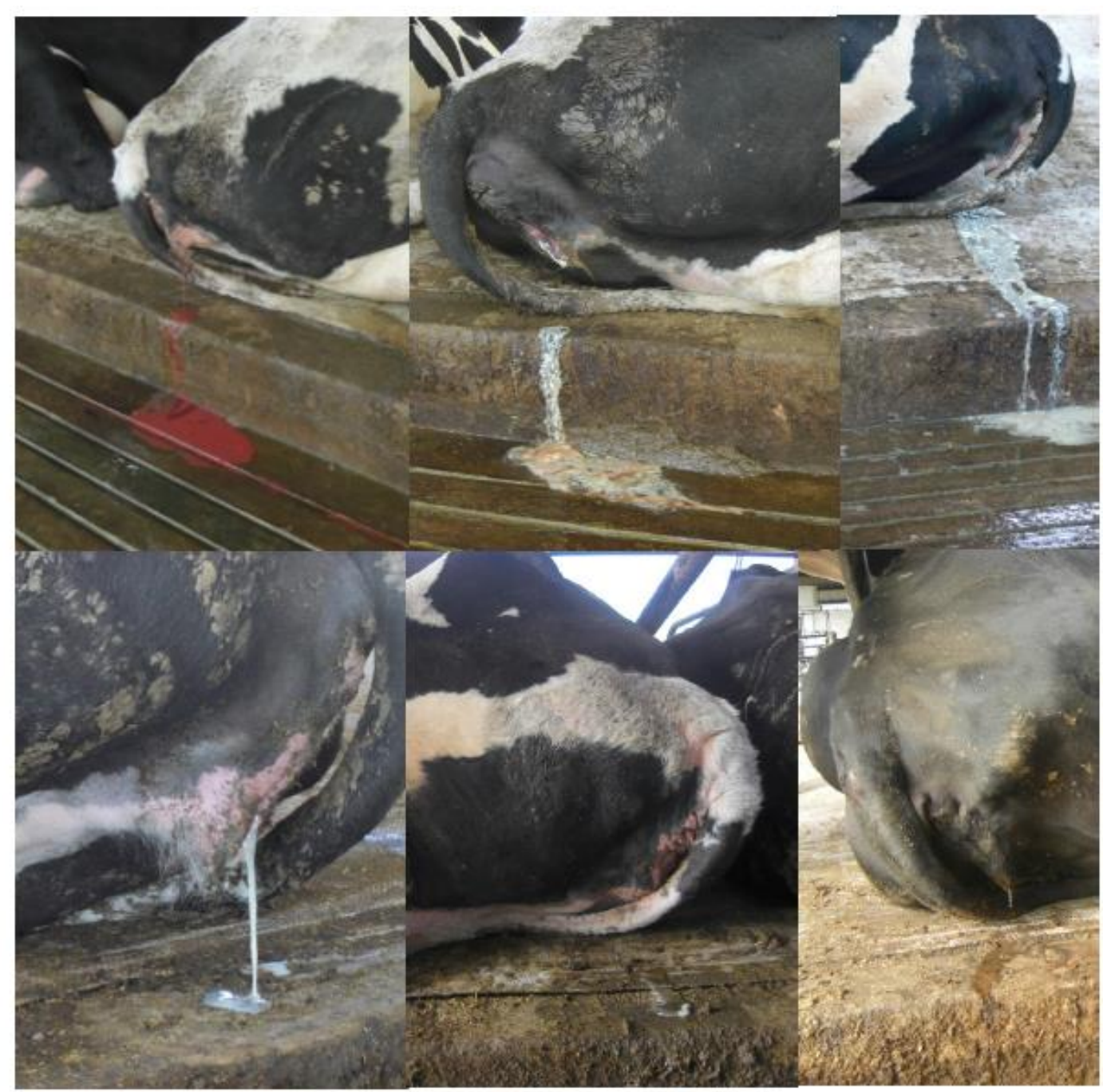

Figura-2. Aspecto da secreção cérvico-vaginal após o parto: A) sanguinolenta; B) sanguinopurulenta; C) purulenta; D) mucopurulenta; E) estriações de pus; F) cristalina. (arquivo pessoal) 


\section{MATERIAL E MÉTODOS}

\subsection{ANIMAIS}

O experimento foi realizado em uma Fazenda comercial próxima de Ithaca, localizada na rodovia Indian Field, número 2231, na localidade de Scipio Center, Nova York. Foram utilizadas vacas Holandesas (Bos taurus taurus), multíparas e primíparas (entre 1 e 6 lactações), durante o pré-parto e início de lactação, com escore de condição corporal variando entre 2.5 e 4, em uma escala de 1 a 5 (1 muito magra e 5 obesa), proposta por Widman et al., (1982) e desenvolvida por Edmonson et al., (1989). As vacas (3.450 vacas Holandesas) foram ordenhadas três vezes ao dia, em uma ordenha tipo carrossel, com capacidade para 100 vacas. A média de produção de leite foi de 38.6 litros por vaca/dia. Primíparas e multíparas foram alojadas em galpões do tipo freestall, com piso e baias de concreto, coberta com estrume após passar pelo biodigestor e pela e secagem. Para todas as vacas, foi oferecida uma dieta completa, contendo aproximadamente $55 \%$ de forragem (silagem de milho, capim ensilado e palha de trigo) e $45 \%$ de concentrados (farinha de milho, farelo de soja, canola, caroço de algodão e poupa cítrica) fornecidos três vezes ao dia.

Os animais tiveram acesso a água e sal mineral ad libitum. A dieta foi formulada para suprir, ou ultrapassar a exigência nutricional diária, de uma vaca Holandesa lactante, com peso de $650 \mathrm{Kg}$ e produzindo $45 \mathrm{~kg}$ de leite, com $3.5 \%$ de gordura.

As vacas secas foram estabuladas e separadas em dois grupos: (1) grupo far-off, contendo vacas com 225 até 255 dias de gestação e (2) grupo close-up, formado por vacas com mais de 255 dias de gestação. Novilhas gestantes ( $>255$ dias de gestação) foram alocadas no galpão de vacas secas, 40 dias antes da data prevista para o parto (aproximadamente 240 dias de gestação).

Funcionários da fazenda, eram responsáveis por monitorar o galpão de vacas secas 24 horas por dia, 7 dias por semana. Eles foram treinados para detectar vacas no estágio 1 e 2 do parto e mudá-las do lote close-up, para a maternidade que continha 4 lotes, cada um com uma área de $400 \mathrm{~m} 2$, contendo uma cama profunda, feita de capim seco. Uma vez na maternidade, as vacas ficavam em observação durante o parto, sendo apenas realizada a intervenção, quando julgada necessária pelo funcionário responsável. Imediatamente após o parto, os bezerros eram removidos da maternidade e alocados em uma cama de maravalha seca, que continha lâmpadas aquecedoras, para secar e aquecer os bezerros no inverno. Vacas recém- 
paridas, foram ordenhadas pela primeira vez por volta de 4 horas após o parto, em uma ordenha paralela, com capacidade para cinco vacas, presente na área de maternidade. $\mathrm{O}$ manejo reprodutivo, foi realizado com a combinação de uma pré-sincronização (MOREIRA et al., 2001), sincronização e re-sincronização (FRICKE et al., 2003), e posteriormente, detecção de estro. No primeiro serviço, todas as vacas foram pré-sincronizadas e inseminadas pelo uso de um protocolo de inseminação artificial em tempo fixo (IATF). Nos dias $55 \pm 3 \mathrm{e}$ $69 \pm 3$ da lactação, foram injetados 25 mg de PGF2 $\alpha$ (Lutalyse Sterile Solution; Pfizer Animal Health, Parsippany, NJ) e, subsequentemente, os animais foram submetidos ao protocolo Ovsynch (Pursley et al., 1995): $100 \mu \mathrm{g}$ de GnRH (Cystorelin; Merial Ltd., Iselin, NJ) no $81 \pm$ 3 DIM, PGF $2 \alpha$ no $88 \pm 3$, e novamente GnRH $90 \pm 3$ dias em lactação e a inseminação ocorreu em tempo fixo no dia $91 \pm 3$. Após o primeiro serviço, as vacas que não se tornaram gestantes, foram inseminadas após detecção de cio, utilizando um sensor de atividade, fixado no colar, localizado no pescoço dos animais (Alpro, DeLaval, MO). Vacas não detectadas no estro foram colocadas em um protocolo de re-sincronização, que se iniciava $33 \pm 3$ após o primeiro protocolo de IATF (Ovsynch). Na re-sincronização, todas as vacas passaram novamente pelo protocolo de IATF (Ovsynch). Foi repetida a ultrassonografia em vacas diagnosticadas prenhes 21 dias após o primeiro diagnóstico, com o intuito de detectar a viabilidade da prenhez no dia $60 \pm 3$. Mortalidade embrionária no primeiro serviço foi definida como ausência de viabilidade de gestação no dia $60 \pm 3$.

\subsection{DELINEAMENTO EXPERIMENTAL}

Coletaram-se swabs vaginais em duplicata, de 573 vacas, durante o período de março de 2015 a junho de 2015. Todas as vacas no período seco foram avaliadas durante o momento de coleta e não apresentavam sinais clínicos de afecções reprodutivas, claudicação, ou algum outro sinal de doença.

Todas as coletas foram realizadas pela utilização de um swab estéril (Covidien Kendall, Minneapolis, MN). Para tal, limpou-se a vagina externamente com papel toalha e dois swabs vaginais da mesma vaca foram coletados da parte cranial da vagina em um mesmo ponto, rodando 6 vezes e depois retirando-o tomando-se cuidado para evitar contaminação. Os swabs vaginais foram imediatamente colocados em criotubos estéreis, após a coleta e armazenados à $4{ }^{\circ} \mathrm{C}$, por $1 \mathrm{a} 3 \mathrm{~h}$, durante o transporte para o laboratório. Um swab foi utlizado 
para a cultura de meio cromogênico e o outro, armazenado em longo prazo, no freezer, em uma temeratura de $-80^{\circ} \mathrm{C}$.

Amostras foram coletadas de cada vaca nos seguintes pontos: $-7,0,3$, e 7 dias, em relação ao dia do parto, com um intervalo de \pm 1 dia. Amostras no D0 foram coletadas após o parto, com 60 minutos após o nascimento (média de tempo de 20 minutos). As vacas que entraram no estudo foram identificadas e contidas pelo pescoço em canzil. Para evitar a contaminação no diagnóstico de metrites e endometrites, o períneo foi desinfetado, utilizandose uma solução de etanol $70 \%$. O metricheck® foi desinfetado com uma solução de clorexidina à $2 \%$, após o uso. As amostras foram colhidas conforme os procedimentos descritos a seguir: Dia -7, foram coletadas 573 amostras no D0, 304 no D3, 290 no 270 D7 .

Retenção de placenta foi definida, como vacas que falhavam em expulsar suas membranas fetais até 24 horas após o parto. A temperatura foi aferida, utilizando termômetro (GLA M700; GLA Agricultural Electronics, San Luis Obispo, CA),

4 vezes (no $-7,0,3$, e 7 dias relativos com o parto).Temperaturas $\geq 39.5^{\circ} \mathrm{C}$, foram consideradas como febre.

A descarga vaginal de todas as vacas do estudo foram avaliadas por um dos veterinários da equipe, nos dias 4, 7 e 10 após o parto, para o diagnóstico de metrite, utilizando o metricheck ${ }^{\circledR}$ (SimcroTech, Hamilton, New Zealand) e classificada usando-se escala de 5 pontos (escala de 1 a 5), sendo 1, lochia normal, não fétido, viscoso, claro, vermelho ou marrom; 2, descarga de muco, com flocos de pús; 3 , secreção com <50\% pús, mucopurulenta, não fétida com; 4 , descarga mucopurulenta com $\geq 50 \%$ pus, não fétida; 5 , descarga vaginal aquosa, fétida, vermelho-acastanhado (MCDOUGALL et al., 2007; DUBUC et al., 2010).

Vacas com uma pontuação de descarga vaginal $\leq 4$ foram classificados como saudáveis, e foram consideradas com metrite puerperal, animais com tamanho do útero anormal, descarga vaginal fétida, vermelho-acastanhada (escala 5 do metricheck®), com sinais de doença sistêmica (, diminuição da produção de leite, febre e outros sinais de toxemia). A presença de febre $\left(\geq 39.5^{\circ} \mathrm{C}\right)$ e o diagnóstico de metrite foi indicativo de metrite puerperal. As vacas diagnosticadas com metrite foram tratadas pelos funcionários da fazenda, que seguiram um protocolo específico criado por Médicos Veterinários, do ambulatório da Clínica Médica, da Universidade de Cornell. Vacas que apresentaram febre no pós parto, tiveram maior incidência de crescimento bacteriano nesse período. 
A Endometrite clínica, foi definida como presença de descarga vaginal purulenta ou mucopurulenta, depois de 21 após o parto, utilizando o dispositivo Metricheck (SimcroTech), como descrito em estudo prévio (McDougall et al., 2007) 0 - sem muco; 1) muco limpo; 2) muco com poucas estrias de pús; 2) muco com pelo menos $25 \%$ de estrias de pus; 3) muco com 50\% de pús; 4) Muco purulento; 5) muco sero sanguinolento. A classificação 5 era utilizada somente na avaliação de metrite. Vacas com condição 3 de muco já eram consideradas com endometrite.

Dados de saúde foram extraídos do software DairyComp (DairyComp 305, Tulare, CA). Foram usados dados coletados na fazenda para avaliar a presença de mastite, cetose, aborto, parto gemelar, natimortos, distocia, retenção de placenta, deslocamento de abomaso, partos na maternidade e parto noturno, como fatores de risco. Um único pesquisador ficou responsável por determinar o escore de condição corporal utilizando uma escala de 1- 5 pontos, como previamente descrito por (Edmonson et al., 1989).

\subsubsection{Estudo 1}

\section{Extração de DNA}

Para a obtenção de material genético foram utilizados os swabs de 106 vacas do estudo anterior que possuiam os 4 pontos de coleta (D -7, 0, 3 e 7). Cada swab foi embebido em 1,5 $\mathrm{mL}$ de água "DNAse free" em um microtubo com capacidade para $2 \mathrm{~mL}$, onde permaneceram incubados por $2 \mathrm{~h}$, a fim de que as bactérias vaginais se desprendessem. Para tal, utilizou um Mini-Beadbeater-8 (Biospec Products, Bartlesville, OK). O líquido restante foi centrifugado durante 10 minutos, a $13.000 \mathrm{rpm}$, formando um pellet, o sobrenadante foi descartado, e o DNA ,extraído do pellet, com auxílio do Kit PowerSoil DNA Isolation Kit (MO BIO Laboratory Inc., Carlsbad, CA) seguindo as recomendações do fabricante.

A concentração e a pureza do DNA foram avaliadas com auxílio de um espectrofotômetro NanoDrop ND-1000 (NanoDrop Technologies, Rockland, DE) com o comprimentos de onda de 230, 260 e $280 \mathrm{~nm}$.

PCR quantitativo 
Para determinar o CBT preparou-se um padrão das amostras de swab vaginal, e os plasmídeos foram clonados como descrito anteriormente por BICALHO et al., 2017, e NONNENMACHER et al. (2004). Para isso foi utilizado o kit de clonagem Zero Blunt TOP PCR (Life Technologies, Darmstadt, Alemanha). O plasmídeo foi purificado com auxilio de um Kit comercial (QIAprep Spin Miniprep- Qiagen, Valência, CA) e quantificado utilizando Quant-iT PicoGreen e um DsDNA Broad Range Assay Kit (Life Technologies, Carlsbad, CA). A confirmação da inserção do plasmídeo foi realizada em gel de agarose por eletroforese, e por sequenciamento do plasmídeo no Cornell University Life Science Core Laboratories Center.

Os números de cópias do gene do rDNA $16 \mathrm{~S}$ foram quantificados por PCR quantitativa (qPCR). A PCR foi realizada em $15 \mu \mathrm{L}$ de volumes compostos por, $1 \times$ iQ Sybr Green Supermix (BioRad Laboratories, Hercules, CA), $300 \mathrm{nM}$ cada iniciador, e $3 \mu \mathrm{L}$ de DNA genômico. As condições do termociclador foram as seguintes: desnaturação a $95^{\circ} \mathrm{C}$ durante $3 \mathrm{~min}, 40$ ciclos de amplificação $\left(95^{\circ} \mathrm{C}\right.$ durante $10 \mathrm{~s}, 55^{\circ} \mathrm{C}$ durante $30 \mathrm{~s}$ ), e 2 passos finais a $95^{\circ} \mathrm{C}$ durante 1 min e $55^{\circ} \mathrm{C}$ durante 1 min, seguido pela determinação da curva de fusão. Todas as reações foram realizadas em duplicata usando o sistema de detecção de PCR Real-Time (Bio-Rad Laboratories). A quantificação do DNA-alvo do rDNA 16S foi alcançada por diluições em série de 10 vezes, variando de 100 a 107 cópias de plasmídeos, dos padrões de plasmídeos previamente quantificados. Os padrões de plasmídeos e amostras de swab vaginal foram executados em duplicata. Foi utilizada a média do valor de limiar de ciclo, para calcular o valor da carga bacteriana.

\section{Amplificação por PCR do gene $16 \mathrm{~S}$ rDNA}

Das 111 vacas selecionadas, foi realizado o sequenciamento do gene 16S rDNA foi realizada em todas amostras que tinham um conjunto completo, dos 4 pontos de coleta, dos esfregaços vaginais $(n=106)$.

O gene do rDNA 16s foi amplificado por PCR, utilizando o sequenciador miseq (illumina, inc., san diego, ca) e kits de química v2 (300 ciclos). Para amplificar da região hipervariável de v4 do gene rDNA 16s bacteriano, foram utilizados primers $515 \mathrm{f}$ e $806 \mathrm{r}$ de acordo com métodos previamente descritos e otimizados para o illumina miseq. (Llumina, inc., San Diego, CA), como descrito por Caporaso et al., (2012). As condições de PCR para 
amplificação do gene do rDNA $16 \mathrm{~S}$, incluíram, uma desnaturação inicial a $94{ }^{\circ} \mathrm{C}$ durante 3 minutos, seguido de 35 ciclos de $94{ }^{\circ} \mathrm{C}$ durante $45 \mathrm{~s}, 50^{\circ} \mathrm{C}$ durante 1 min e $72{ }^{\circ} \mathrm{C}$ por $90 \mathrm{~s}$, e depois seguido da etapa de alongamento a $72{ }^{\circ} \mathrm{C}$ durante $10 \mathrm{~min}$.

Antes do sequenciamento, os amplicons replicados foram reunidos e purificados com um auxilio de um Kit comercial (QIAquick PCR Purification Kit- Qiagen) e analisado por eletroforese usando 1,2\% (peso / volume) de géis de agarose corado com 0,5 mg / mL de brometo de etídio. Foram adicionados controles negativons, nos quais não havia DNA.

Sequenciamento e bioinformática

As alíquotas das amostras amplificadas de swabs foram padronizadas para a mesma concentração e agrupados em 5 corridas de seqüência diferentes de acordo com iniciadores de código de barras individuais para o gene 16D rDNA. As bibliotecas equimolares finais foram sequenciadas usando o kit reagente MiSeq v2 (300 ciclos) na plataforma MiSeq (Illumina Inc.). As sequências do gene do rDNA $16 \mathrm{~S}$ foram processadas através do softaware pipeline de código aberto Insights . As sequiências foram filtradas por qualidade usando diretrizes estabelecidas (Bokulich et al., 2013). As seqüências foram agrupadas em unidades taxonômicas operacionais (OTU) com base em 97\% de identidade utilizando UCLUST (Edgar, 2010) contra o banco de dados de referência Greengenes, maio Versão de 2013 (McDonald et al., 2012). Baixa abundância os clusters foram filtrados e as sequências quiméricas foram removidas usando USEARCH (Edgar, 2010). Foram comparada as seqüências representativas para cada OTU, contra o Base de dados Greengenes, para atribuição de taxonomia e utilizou-se apenas leituras de comprimento completo e de alta qualidade $(-\mathrm{r}=0)$ para análise. A classificação MiSeq Reporter é com base na base de dados Greengenes (http: // greengenes. lbl.gov/), e a saída é uma classificação de leituras em vários níveis taxonômicos: reino, filo, classe, ordem, família, gênero e espécie. Uma saída do índice Shannon foi gerada pelo pipeline QIIME.

Comunidade bacteriana.

A comunidade foi composta por 3 espécies bacterianas: Escherichia coli, Staphylococcus aureus e Fusobacterium necrophorum. As culturas puras microbianas foram transferidas separadamente para apropriados meio de crescimento líquido, até a fase tardia ou 
estacionária inicial. Rapidamente, as cepas de E. Coli foram cultivadas aerobicamente no meio Luria-Bertani (Sigma-Aldrich, St. Louis, MO) a $37^{\circ}$ C. Foram inoculados com $1 \%$ de uma cultura durante a noite e crescidos em $100 \mathrm{~mL}$ de meio, com agitação (150 rpm). Similarmente, Staphylococcus aureus e Fusobacterium necrophorum cresceram em Versa TREK REDOX 1 (Trek Diagnostic Systems, Independence, Similarmente, Staphylococcus aureus e Fusobacterium necrophorum foram cultivados em VersaTREK REDOX 1 (Trek Diagnostic Systems, Independence, $\mathrm{OH})$ em $7 \%$ de $\mathrm{CO} 2$ a $37^{\circ} \mathrm{C}$, e VersaTREK REDOX 2 (Trek Diagnostic Systems) anaerobicamente a $37^{\circ} \mathrm{C}$, respectivamente

Quantificação de Bactérias por qPCR.

Extraiu-se o DNA de todas as amostras usando um kit de isolamento de DNA microbiano PowerSoil (MO BIO Laboratory Inc.,Carlsbad, CA) seguindo o protocolo do fabricante. Todos os DNAS extraídos foram quantificados usando um espectofotômetro NanoDrop ND-1000 (NanoDrop Technologies). Cada amostra foi quantificada em duplicado e o DNA foi agrupado em proporções variáveis para gerar a comunidade simulada. Para determinar o CBT, quantificamos o rDNA $16 \mathrm{~S}$ obtido da comunidade simulada comparando-o com DNA padrão (diluição em série do nosso $16 \mathrm{~S}$ clone do gene rRNA) usando uma curva de calibração. O CBT de cada comunidade simulada foi definida como a cópia log10 número do gene 16D rDNA. Confirmamos a caracterização filogenética da comunidade simulada por amplificando a região hipervariavel de V4 da bactéria 16S rDNA genes conforme descrito anteriormente.

\subsubsection{Estudo 2}

No estudo 2, um dos swabs coletado, foi utilizado imediatamente para cultura bacteriana em placa, contendo meio cromogênico (Accumast ${ }^{\circledR}$ ). O plaqueamento foi realizado em cada uma das três seções, assegurando que o swab tenha sido saturado na placa. As placas foram incubadas em uma estufa, aerobicamente à $37^{\circ} \mathrm{C}$ por 24 horas. A amostra foi considerada positiva a partir da presença de uma ou mais colônias numa única seção da placa, para o crescimento bacteriano utilizando o Accumast ${ }^{\circledR}$. O Atlas abaixo foi utilizado para identificar quais bactérias cresceram no meio de cultura. 

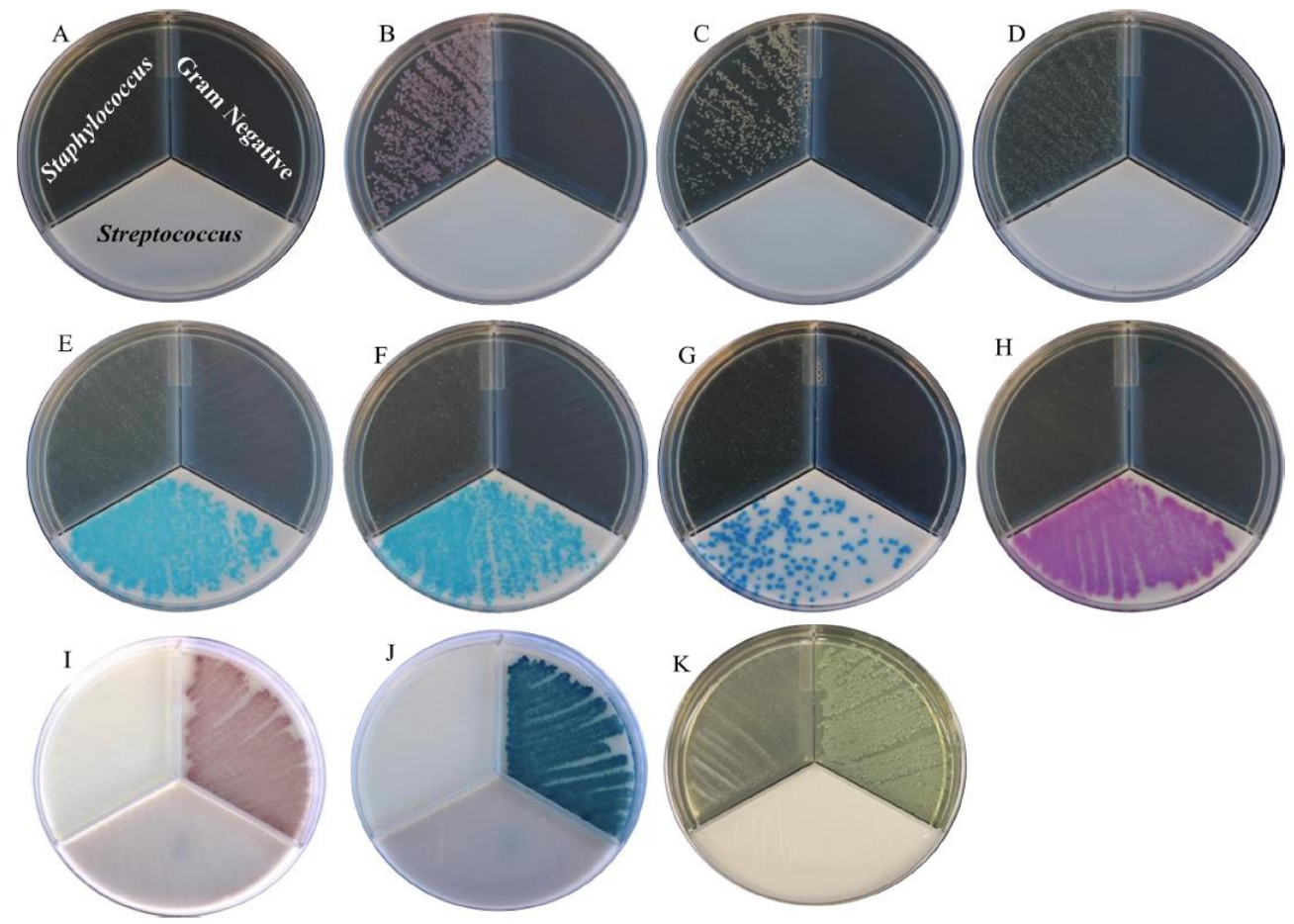

Figura-3. Avaliação visual do crescimento bacteriano em placas Accumast realizadas em laboratório. Placa sem bactérias ( A ), Staphylococcus aureus ( B ), Staphylococcus epidermidis ( C ), Staphylococcus chromogenes ( D ), Streptococcus agalactiae ( E ), Streptococcus dysgalactiae ( F ), Streptococcus uberis ( G ), Enterococcus faecalis ( H ), Escherichia coli ( I ), Klebsiella oxytoca ( J ), e Pseudomonas aeruginosa ( K ). (fonte)

\subsection{Análise estatística}

\subsubsection{Estudo 1}

Foram utilizados dados a partir da análise de bioinformática, para descrever a abundância relativa de filo e gênero microbiano nas amostras de swab vaginal. O perfil da microbiota foi descrito para prevalência de phyla e gêneros usando a função tabulate do JMP Pro 11 (SAS Institute Inc., Cary, NC). Foi utilizado o teste t de Student, para comparar as diferenças na abundância relativa do filo bacteriano entre doenças reprodutivas e amostras de vacas saudáveis; e entre vacas gestantes e não gestantes (primeiro serviço). Diferença com um 
valor de $\mathrm{P} \leq 0,05$ foi considerado significativo, e aqueles com um valor de $0,05<\mathrm{P} \leq 0,10$ foram considerados tendência.

Os resultados da ANOVA foram ajustados aos dados usando o procedimento de modelos lineares gerais no JMP Pro 11 (SAS Institute Inc.) para avaliar os efeitos das variáveis independentes (RP, metrite, endometrite, febre, parto assistido, paridade) do bezerro (macho, fêmea, natimorto, e gêmeos) e nas variáveis dependentes (CBT e carga bacteriana específica de filo). Todos os valores $\mathrm{P}$ da ANOVA foram corrigidos por um FDR de 0,05 usando o método Benjamini-Hochberg, e valores P corrigidos por FDR abaixo de 0,05 (FDR <0,05) foram consideradas significativas. Finalmente, foram utilizadas análises de regressão linear simples para identificar a correlação entre CBT em d 3 e d 7 e a presença de febre em d 3 e em d 7 relativo ao parto.

\subsubsection{Estudo 2}

As informações individuais das vacas foram dispostas em uma única planilha, para a realização das análises estatísticas.

Para todas as análises de variáveis binomiais, utilizadas para comparar o crescimento bacteriano, entre doenças reprodutivas (RP, metrite, endometrite, febre, parto assistido, paridade), fatores ligados ao bezerro (macho, fêmea, natimorto, e gêmeos) e amostras de vacas saudáveis; foram utilizadas regressões logísticas, processadas no software R Studio (versão 3.2.3) O nível de significância utilizado para todos os dados obtidos foi $\mathrm{P}<0,05 \mathrm{e}$ tendências estatísticas como $\mathrm{P}<0,10$ foi considerado.

A razão de chances ou razão de possibilidades (em inglês: odds ratio; abreviatura O.R.) é definida como a razão entre a chance de um evento ocorrer em um grupo e a chance de ocorrer em outro grupo. Chance ou possibilidade é a probabilidade de ocorrência deste evento dividida pela probabilidade da não ocorrência do mesmo evento. O OR foi calculado pelo software R Studio (versão 3.2.3) O nível de significância utilizado para todos os dados obtidos foi $\mathrm{P}<0,05$ e tendências estatísticas como $\mathrm{P}<0,10$ foi considerado. 


\subsection{RESULTADOS E DISCUSSÃO ESTUDO I}

No total, foram avaliadas amostras de 106 vacas, sendo 41 (38,6\%) primíparas e 65 $(61,3 \%)$ multíparas. A incidência de RP foi de 7,5\% ( $n=8)$, de metrite $21,6 \%(n=23)$ e de endometrite $10,3 \%(n=11)$. A porcentagem de vacas gestantes no primeiro serviço foi de $37,7 \%(\mathrm{n}=40)$.

CBT Utilizando PCR, e estimativa da carga de Proteobacteria, Fusobacteria, Bacteroidetes, e Mannheimia

A CBT média das amostras vaginais de todos os 106 animais, no momento do parto (d0), foi de 3,96 \pm 0,063 $\log 10$ cópias do gene16S no d-7; 3,96 \pm 0,061 log10 cópias do gene $16 \mathrm{~S}$ 4,40 \pm 0,089 $\log 10$ cópias do gene $16 \mathrm{~S}$ rDNA, no d3; e 4,45 \pm 0,091 $\log 1016 \mathrm{~S}$ cópias do gene rDNA, no d7 (dias relativos ao parto)

A CBT não diferiu significativamente no pré-parto, entre d -7 e $0(\mathrm{P}=0,96)$; entretanto aumentou significativamente em d 3 e d7 pós-parto $(\mathrm{P}<0,001)$. Tal resultado é semelhante ao de outros autores, que encontraram contaminação do lúmen uterino, na grande maioria das vacas, nas primeiras duas semanas após o parto, devido à abertura da cérvice (ELLITOT et al., 1968; BEKANA; KINDAL, 1996). Houve uma tendência a uma maior CBT no d3 $(P=0,06)$, nas vacas que apresentaram retenção de placenta, quando comparada com as vacas sem RP, essa diferença foi significativamente maior no d7 (P <0,001; GRÁFICO 1A), Jeon et al (2015) relataram que, fatores de risco para doenças uterinas (distocia, gêmeos, paridade e RP), foram associados ao aumento da CBT em vacas leiteiras. Vacas diagnosticadas com febre apresentaram diferenças significativas na CBT no d3 e d7, quando comparadas com vacas sem febre $(\mathrm{P}<0,001$; Gráfico 1B), semelhante os resultados obtidos por Santos e Bicalho (2012), onde os filos Fusobacteria, Proteobacteria, e Bacteriodetes, foram relacionados com febre pós-parto e doenças uterinas. Vacas que tiveram metrite, apresentaram CBT significativamente maior no d7. Entretanto, apresentaram uma diversidade microbiana significativamente menor no parto do que vacas saudáveis $(\mathrm{P}<0,001$; Gráfico 1C). Vacas que tiveram endometrite apresentaram maior CBT no d3 $(\mathrm{P}<0,001)$ e houve uma tendência a apresentar uma maior CBT no $\mathrm{d} 7$ do que vacas sem endometrite $(\mathrm{P}=0,08$; Gráfico 1D), indicando que, quando a disbiose se instala, ocorre a proliferação de um grupo 
específico de agentes patogênicos oportunistas (Fusobacteria e Bacteroidetes), diminuindo a diversidade bacteriana e aumentando significativamente o CBT.

Gráficos 1 (A, B, C e D). Carga bacteriana total ( $\log 10$ 16S rDNA) detectado em amostras vaginais em vacas leiteiras, diagnosticadas com (A) retenção de placenta, (B) febre, (C) metrite, e (D) endometrite clinica comparada com as vacas saudáveis contemporâneas no $\mathrm{d}-7,0,3$, e 7 relativo ao parto. $* * * \mathrm{P}<0.001$.
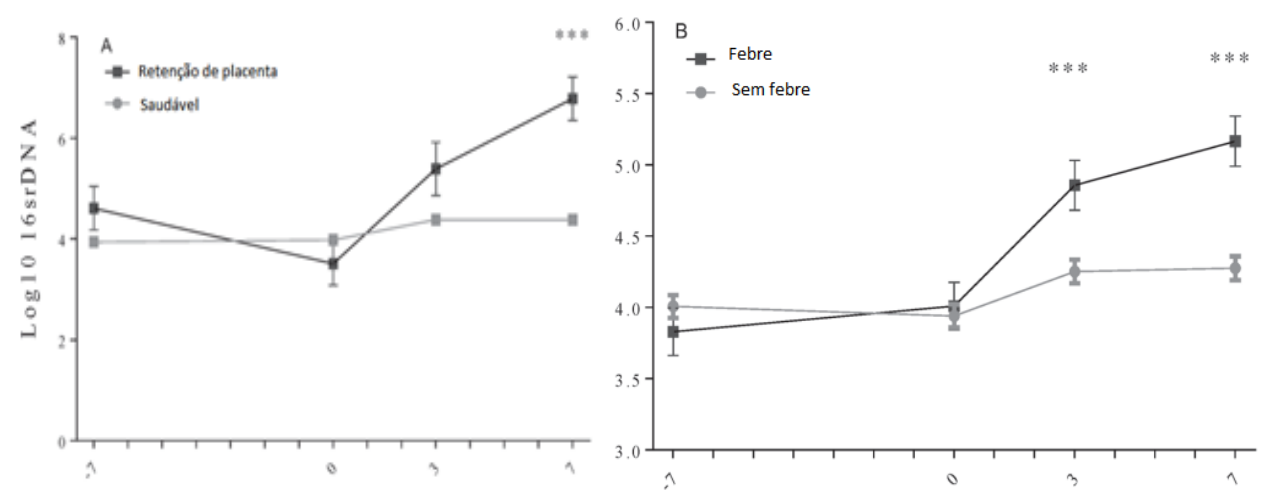

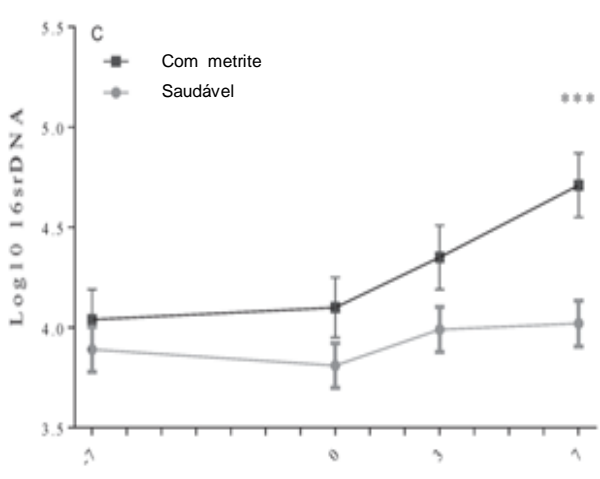

Dias relativos ao parto

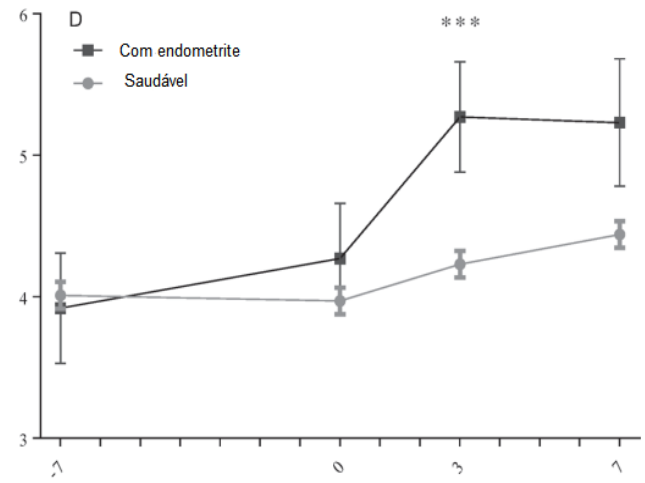

Dias relativos ao parto

Primíparas apresentaram CBT significativamente maior no d 3 e d 7 quando comparadas àsmultíparas $(\mathrm{P}<0,001$; Gráfico $2 \mathrm{~A})$. Esse fato se explica pela maior necessidade de assistência ao parto nas primíparas, o que resulta em aumento do trauma tecidual e necrose do útero, diminuindo o fluxo sanguíneo e a migração de neutrófilos, proporcionando a proliferação bacteriana (DHAKAl et al., 2013; GIULIODORI et al., 2013). Não houve diferença na CBT de vacas gestantes, quando comparadas com vacas não gestantes $(\mathrm{P}=0,18$; Gráfico 2B). No entanto, vacas não gestantes apresentaram menor diversidade microbiana em d 7 do que vacas prenhes ao primeiro serviço. Isto é indicativo de que a microbiota de vacas não gestantes é composta por uma menor diversidade de microorganismos. Esses resultados 
são complementares aos do estudo de Williams et al. (2007), que mostraram que a contaminação do lúmen uterino por patógenos bacterianos, em d 7 pós-parto, prejudica a fertilidade ao reduzir o desenvolvimento do folículo dominante e as concentrações plasmáticas de estradiol. Vacas que pariram gêmeos apresentaram um CBT maior do que vacas que pariram um único bezerro ou natimortos $(\mathrm{P}<0.001$; Gráfico $2 \mathrm{C}$ ), semelhante aos resultados encontrados por Linden et al., (2009), onde natimortos e bezerros machos foram associados a um aumento da incidência de doenças uterinas (BICALHO et al., 2007; LINDEN et al., 2009). Vacas distócicas tiveram uma CBT maior no d3 e d7 do que as vacas eutócicas ( $\mathrm{P}<0,001$; Gráfico 2D). $\mathrm{O}$ aumento na CBT no d7, em vacas com RP e vacas com metrite, pode ser explicado devido às maiores cargas bacterianas de Fusobacteria e Bacteroides, quando comparadas com vacas saudáveis ( $\mathrm{P}<0,001$; Figura 3). Vários fatores (primíparas, gestação e prenhez gemelar) foram associados a um maior risco de distocia, e consequentemente de doenças uterinas. Isso se deve ao trauma tecidual, que ocorre nas intervenções obstétricas, favorecendo o desenvolvimento de bactérias patogênicas (Fusobacteria e Bacteroidetete) no lúmen uterino (CORREA et al., 1993; KANEENE E MILLER, 1994; DUBUC et al., 2010; BICALHO et al, 2012).

Gráfico 2 (A, B, C e D). Carga bacteriana total (log10 16S rDNA) em amostras vaginais em vacas leiteiras, (A) vacas multíparas e primíparas, (B) prenhez ao primeiro serviço , (C) categoria de bezerro e (D) parto assistido ou normal. $* * * P<0.001$., comparada com as vacas saudáveis, no $\mathrm{d}-7,0,3$, e 7 relativa ao parto. $* * * \mathrm{P}<0.001$. 

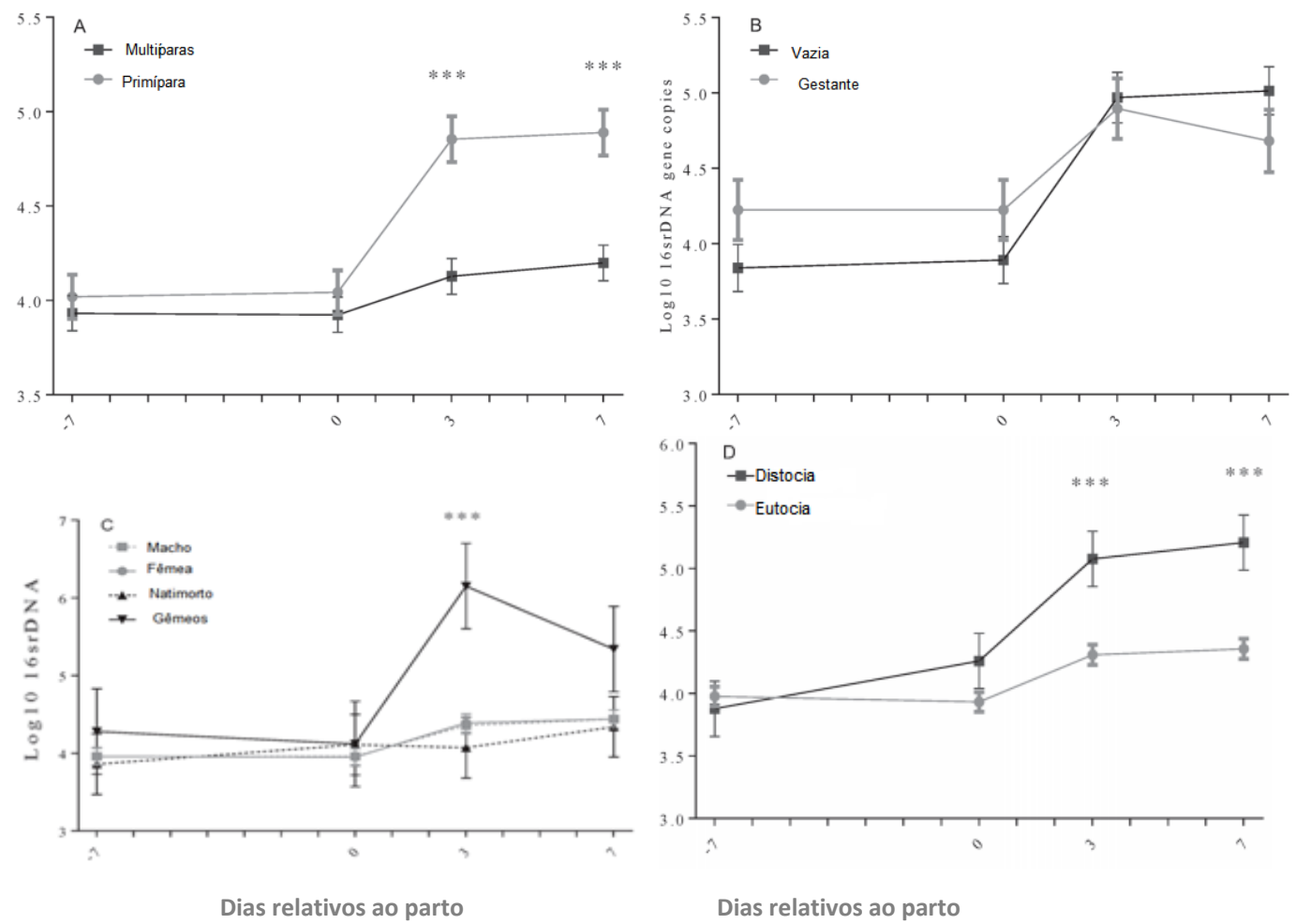

Gráfico 3. Carga estimada de Proteobactérias, Fusobactérias e Bactoroide (A-C) (D-F) e (G-I), respectivamente, encontradas em amostras vaginais de vacas leiteiras com placenta retida (RP), metrite e endometrite clínica, em comparação com vacas saudáveis, nos quatro pontos de coleta. O eixo y indica o $\log 10$ $16 \mathrm{~S}$ rDNA da carga estimada para Proteobacteria, Fusobacteria e Bacteroidetes. $* * * \mathrm{P}<0,001$. 

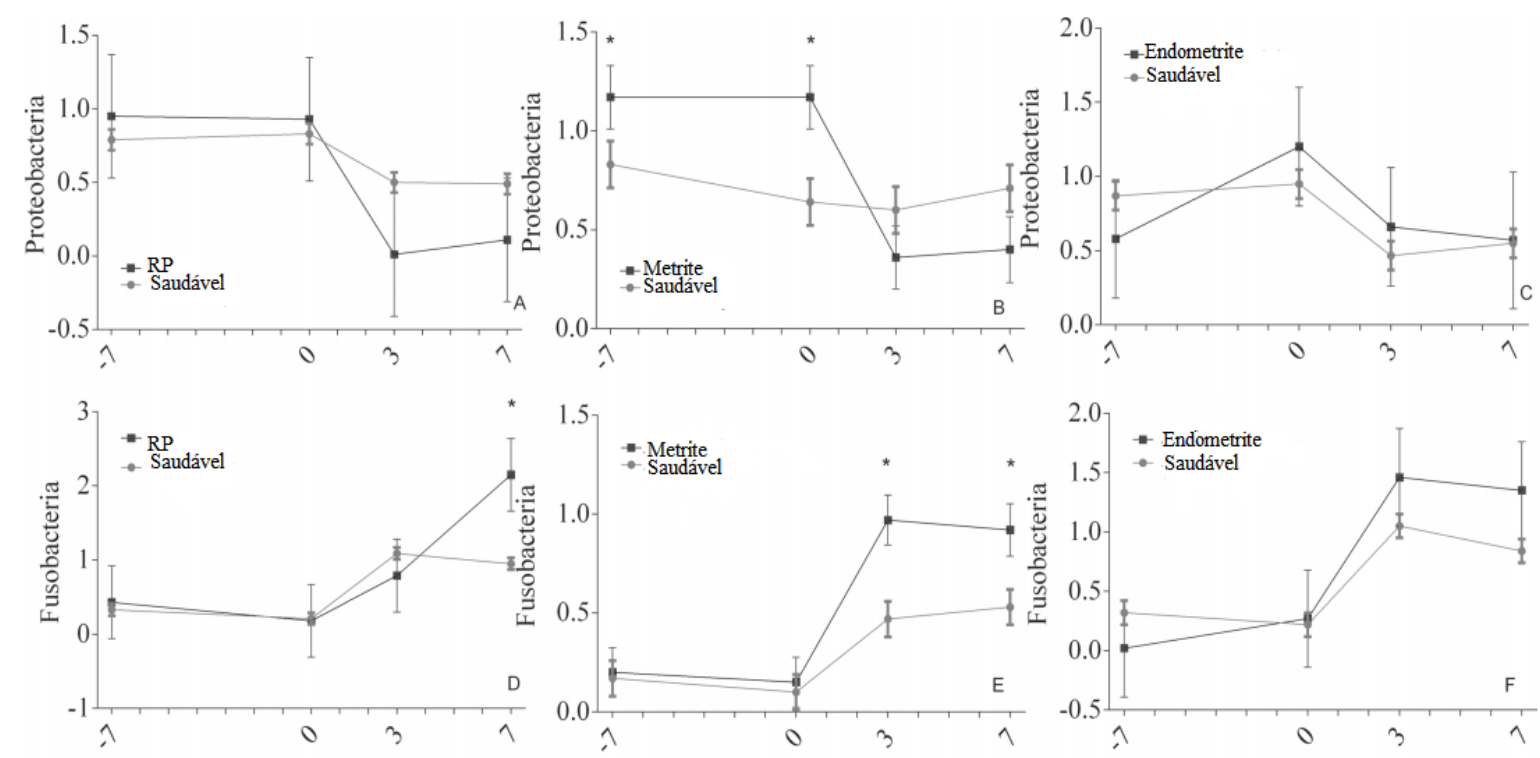

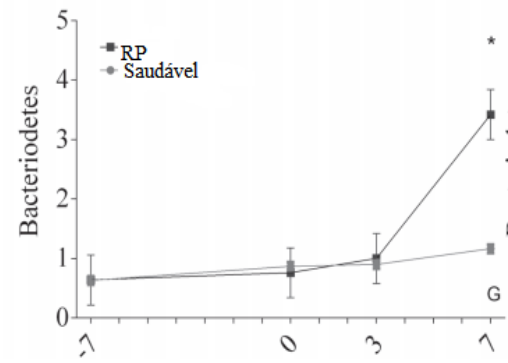

Dias relativo ao parto

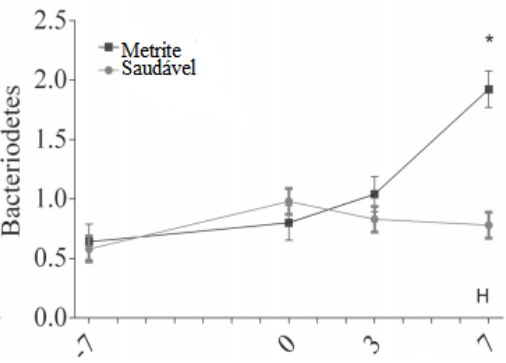

Dias relativos ao parto

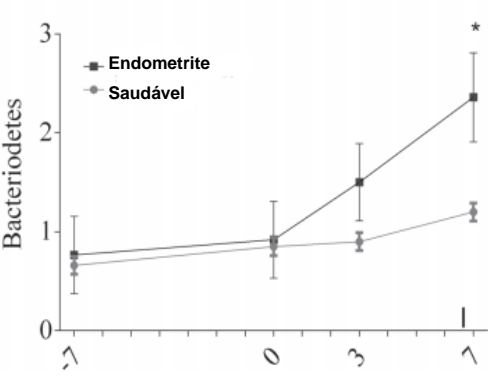

Dias relativos ao parto

Vacas com metrite apresentaram maior carga bacteriana de Proteobactérias, no préparto e no parto (d-7, P <0,005; d0, P <0,001), do que vacas saudáveis no pós-parto (Gráfico 4), indicando que uma carga estimada de Proteobactérias no pré-parto precede um aumento no número de Bacteroidetes e Fusobacteria na vagina de vacas leiteiras, com metrite, no pós parto. A carga de Bacteroidetes em d7 também foi maior em vacas que desenvolveram RP, metrite e endometrite, do que em vacas que permaneceram saudáveis ( $\mathrm{P}<0,001$; Gráfico 4). Vacas sem febre mostraram cargas bacterianas significativamente mais baixas de Proteobactérias no D0. Vacas que apresentaram distocias, tiveram maiores cargas de Fusobacteria e Bacteroidetes no d3 e d7, respectivamente, do que vacas eutócicas $(\mathrm{P}<0.001$; Figura 4). A presença de alguns grupos específicos de agentes patogênicos (por exemplo, Fusobacteria e Bacteroidetes), nas amostras pós-parto, de vacas com doenças uterinas, é indicativa de que, quando a disbiose ocorre, as bactérias oportunistas se sobrepõem e contribuem para a infecção uterina. As vacas com infecção uterina apresentaram menor diversidade microbiana ao parto do que as vacas saudáveis, indicando que o aumento da 
colonização microbiana está associado à redução da diversidade bacteriana. (OIKONOMOU et al., 2013). Além disso, a antibioticoterapia não foi iniciada antes do início do diagnóstico clínico para metrite, sugerindo que esta redução na diversidade bacteriana, provavelmente estava associada ao desenvolvimento da própria doença. Proteobacteria foi o único filo presente em cargas significativamente maiores nos d-7 e d0 em relação ao parto, em vacas diagnosticadas com metrite puerperal, indicando que uma alta carga bacteriana de Proteobactérias, no pré parto, precede, no pós parto, um aumento no número de Bacteroidetes e Fusobacteria, na vagina de vacas leiteiras com metrite. Os filos bacterianos mais prevalentes entre todas as amostras foram Firmicutes, Bacteroidetes, Tenericutes, Proteobacteria, Fusobacteria, e Actinobacteria.

Os 20 gêneros mais abundantes na vagina de vacas com doenças uterinas e saudáveis, foram direta ou indiretamente relacionados ao trato gastrointestinal, principalmente Bacteroide, Fusobacterium, Ruminococcus, e Clostridium. Esses dados suportam a hipótese de que a microbiota encontrada na vagina das vacas, está presente, tanto em vacas doentes, quanto em vacas saudáveis, provavelmente originárias das fezes de fêmeas adultas (WANG et al., 2013; LAGUARDIA-NASCIMENTO et al., 2015).

Não foi encontrada uma associação específica entre a CBT de Proteobacteria, Bacteriodetes ou Fusobactérias relacioanadas com a fertilidade.

Gráfico 4. Carga bacteriana estimada de Proteobactérias (A-B), Fusobactérias (C-D) e Bacteroidetes (EF), detectados em amostras vaginais de vacas leiteiras em d -7, 0, 3 e 7 em relação ao parto. A febre foi considerada c presente quando a temperatura retal foi $>39,5^{\circ} \mathrm{C}$. $* * * \mathrm{P}<0,001$. 

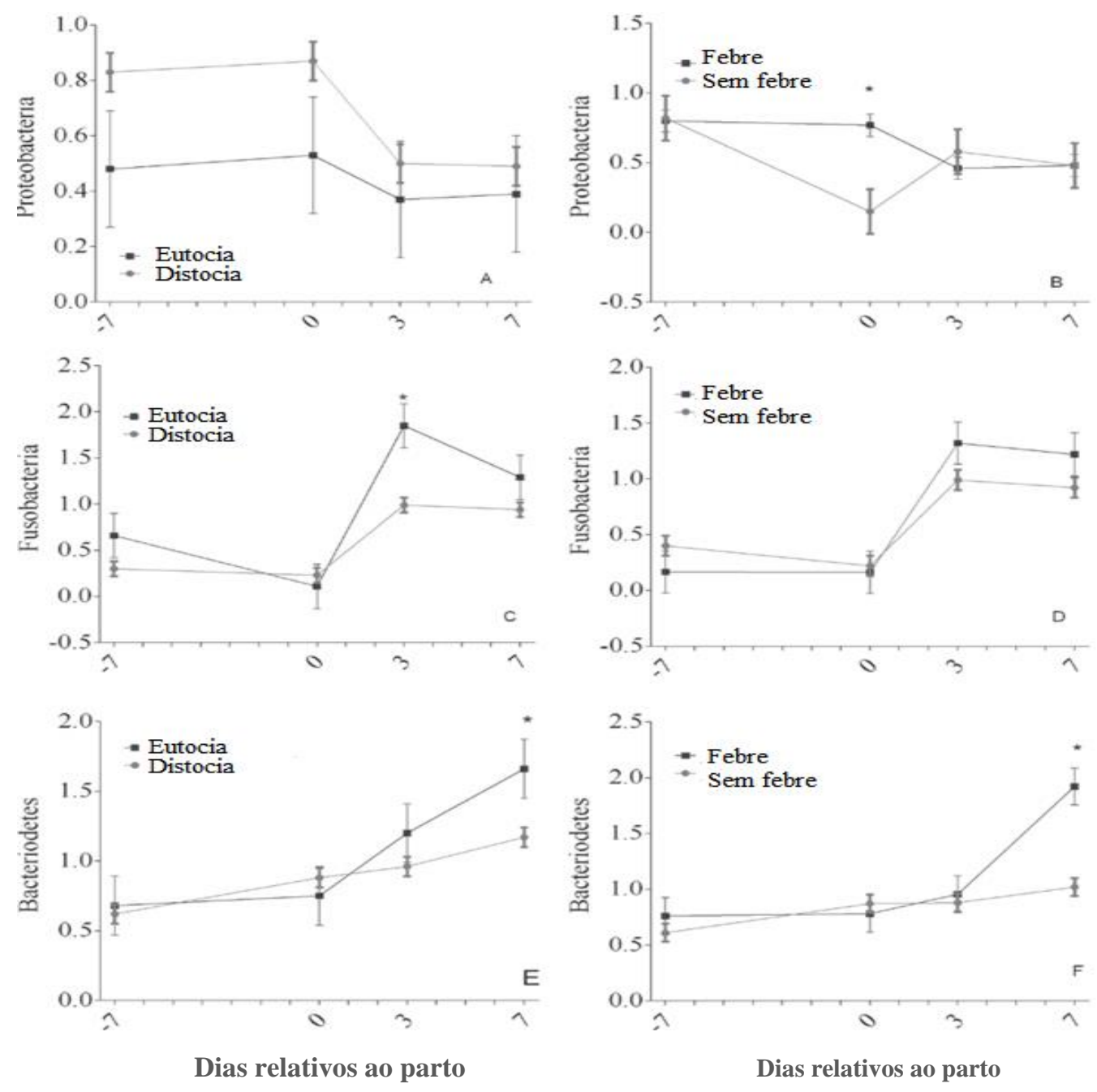

No d-7, as vacas com metrite apresentaram maior carga de Mannheimia do que vacas saudáveis ( $\mathrm{P}<0,001$; Figura 5). No entanto, esses resultados contradizem os estudos de Swartz et al. (2014), em que Aggregatibacter era o gênero predominante nas amostras vaginas. Dois gêneros inéditos foram encontrados nas amostras de swabs vaginais: Gallibacterium e Mannheimia, ambos encontrados no trato respiratório (BISGAARD, 1993; LIMA et al., 2016). Todas as amostras apresentaram Mannheimia, porém não houve diferença na carga bacteriana em vacas com doenças uterinas ou saudáveis. Por outro lado, vacas que tiveram metrite, apresentaram cargas bacterianas maiores de Mannheimia no d -7, quando comparadas a vacas saudáveis. No entanto, esses resultados contradizem os estudos de Swartz et al. (2014), em que Aggregatibacter era o gênero predominante nas amostras vaginas. 
Gráfico 5 Carga estimada de Mannheimia detectada em amostras vaginais de vacas leiteiras com metrite, comparada com saudáveis, em d -7, 0, 3 e 7 em relação ao parto. ${ }^{* * *} \mathrm{P}<0,001$.

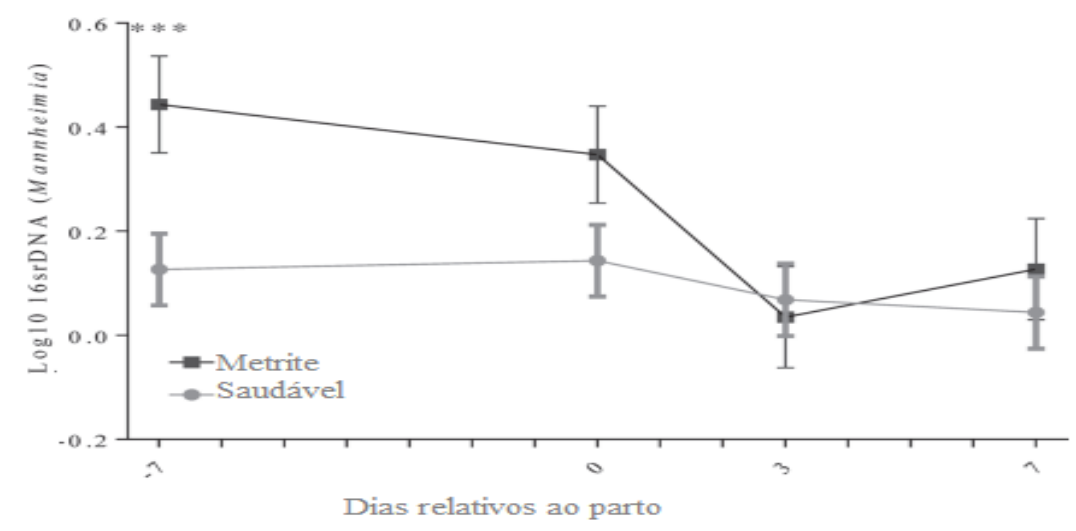

As vacas com febre apresentaram maior carga de Proteobactérias estimada no parto ( $\mathrm{P}$ $<0,001$ ) e uma maior carga estimada de Bacteroidetes em d7 (P <0,001; Gráfico 4) que vacas sem febre. Foi encontrada uma correlação positiva entre CBT e temperatura retal, aferida no d $7(\mathrm{R} 2=0,40, \mathrm{P} \leq 0,001$; Gráfico 6). Os resultados corroboram com um estudo de Sheldon et al., (2004), que correlacionaram a presença de patógenos uterinos específicos, como Prevotella spp. e um gênero de Bacteroidetes após o parto, associado com febre. Nesse estudo, foi utilizado um método padrão, baseado em meio de cultura para identificar bactérias, que tendem a propiciar o desenvolvimento de microorganismos de rápido crescimento. Entretanto esse método excluiu algumas bactérias exigentes e não cultiváveis. A associação indireta entre Bacteroidetes e a presença de febre também pode ser vista no estudo conduzido por Jeon et al. (2015), onde a abundância de Bacteroidetes foi positivamente correlacionado com Fusobacteria, e esta, altamente associada à presença de febre e conseqüentemente metrite.

Gráfico 6. Regressão linear que ilustra a relação entre a carga bacteriana (número de cópia $\log 10$ do gene $16 \mathrm{~S}$ rRNA) em amostras vaginais de vacas leiteiras coletadas em d 7, e a temperatura retal aferida no D7 em relação ao parto. 


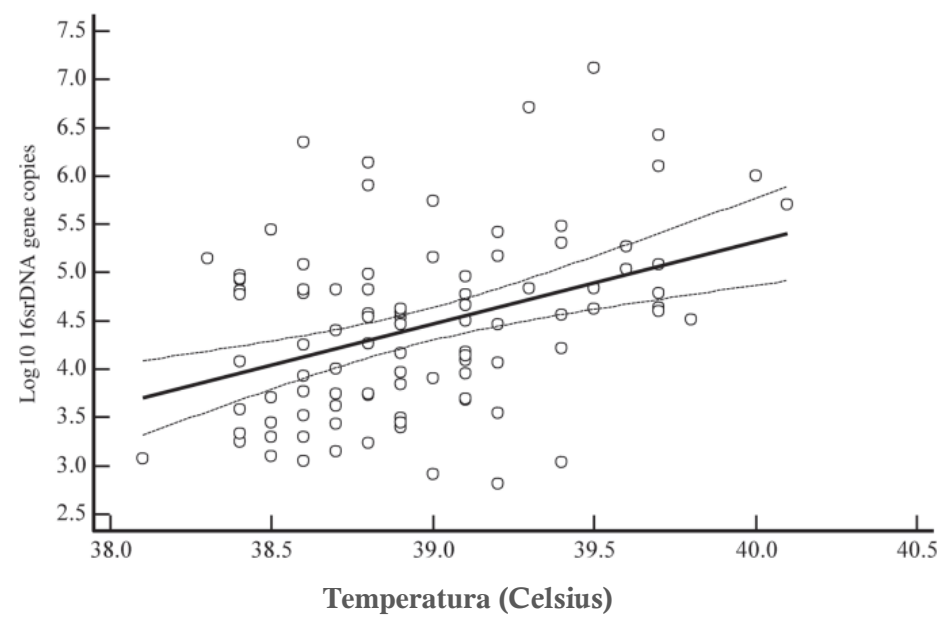

\subsection{RESULTADOS E DISCUSSÃO ESTUDO 2}

A incidência de metrite foi de $19,5 \%$, de mastite $17,4 \%$, Cetose $6,8 \%$, aborto $4,5 \%$, parto gemelar $1,2 \%$, natimorto $5 \%$, distocia $15,1 \%$, retenção de placenta $4,1 \%$, deslocamento de abomaso $1,9 \%$, mastite $17,4 \%$, parto noturno $44,3 \%$.

Foram fatores de risco para metrite, a cetose, parto na maternidade e retenção de placenta $(\mathrm{P}<0,001$; Tabela 1). Esses resultados foram semelhante aos encontrados por Foldi et al, (2006), onde fatores ambientais e metabólicos foram responsáveis pelo aumento na incidência de metrite. As vacas que pariram na maternidade, tiveram maior risco de apresentar metrite, quando comparadas às vacas que pariram no curral. Parece óbvio pensar que a falta de higiene no ambiente do parto possa ser um fator predisponente para o desenvolvimento bactérias e desenvolvimento de doenças intrauterinas. No entanto, nos estudos são apresentados dados conflitantes. A limpeza da região perineal, no momento do parto, foi associada com metrite, segundo Schuenemannet al., (2011), mas diferem dos encontrados por Malinowski et al, (2010), que apontaram a higiene como fator importante para reduzir a incidência de metrite. 
Tabela-1. Incidência de Cetose, retenção de placenta e parto na maternidade como fatores de risco para metrite.

\begin{tabular}{lccc}
\hline & Incidência & $\mathrm{P}$ & Odds ratio \\
\hline Cetose & $6,8 \%(39 / 573$ & $<0,001$ & 3,7 \\
Retenção de palcenta & $4,1 \%(24 / 573)$ & $<0,001$ & 13.6 \\
Partos na maternidade & $92,3 \%(529 / 573)$ & $<0,001$ & 2,8 \\
& & & \\
\hline
\end{tabular}

Parto gemelar foi fator de risco para RP ( $\mathrm{p}<0,001)$, semelhante ao encontrado por vários autores em estudos anteriores (ECHTERNKAMP e GREGORY 1999). Não foram fatores de risco aborto $(\mathrm{P}=0.37)$, natimortos $(\mathrm{P}=0.461)$, e distocia $(\mathrm{P}=0.178$; Tabela 2$)$; entretanto, apesar de não apresentar diferença estatística, animais que apresentaram alterações no parto (aborto, natimorto e distocia) tiveram aproximadamente o dobro de chance de apresentar RP, quando comparados a animais saudáveis. Além disso, a RP aumentou significativamente o risco para metrite $(\mathrm{P}=0.000472 ; \mathrm{P}<0,001)$ e para mastite $(\mathrm{P}=0.0114$; $\mathrm{P}<0,05)$, Esses resultados são semelhantes aos de Joosten et al. (1987), que encontraram maior incidência de RP em vacas que necessitaram de auxílio no parto.

Tabela 2- Fatores de risco para RP.

\begin{tabular}{llc}
\hline & $\mathrm{P}$ & Odds ratio \\
\hline Aborto & 0,37 & 2.0 \\
Natimortos & 0.461 & 1.75 \\
Gêmeos & $<0.01$ & 36.4 \\
Distocia & 0.178 & 1.95 \\
\hline
\end{tabular}

Não houve diferença no desenvolvimento bacteriano de Streptococcus spp. nos dias, -7, 0, 3 e 7 ( $\mathrm{P}<0,05$; Gráfíco 1A). Praticamente todas as vacas, em todos os pontos de coleta, apresentaram crescimento bacteriano no meio de cultura para esse microrganismo. Streptococcus spp são considerados habitantes da microbiota da vulva, vagina, pele e trato gastrintestinal, (OLIVEIRA 1995). Esse resultado diferiu dos encontrados por Rocha et al (2004), que relataram a incidência de Streptococcus spp., em 19.8\% dos swabs vaginais, 
coletadas no pré e pós parto, em vacas da raça Girolanda. Vários autores reportaram que, isolaram Streptococcus spp. como flora adicional e oportunista, sendo encontrado na presença de bactérias patogênicas, porém, sem causar prejuízo a saúde do animal (PANANGALA et al., 1978; KREPLIN 1990). Resultados semelhantes, foram encontrado pot Otero et al (2000), utilizando meio de cultura padrão, no qual reportaram que Streptococcus spp foi a bactéria mais comumente encontrada em amostra de swbs vaginais, e associou Streptococcus $\alpha$ hemolítico, como responsável por característica probióticas na microbiota vaginal, podendo ser utilizado inclusive, na prevenção de infecções do trato reprodutivo das vacas como a metrite, que produz períodos mais longos entre parto e concepção, e conseqüentes perdas econômicas. Entretantanto, outros autores, demonstraram resultados divergentes, apontando que esse microrganismo, favorece a proliferação de bactérias de maior patogenicidade, pois produzem penicilinase, que protegem os agentes responsáveis pelas doenças uterinas (SILVA et al., 1998; SHELDON et al., 2002).

Houve o aumento significativo de E. coli no meio de cultura, proveniente dos swabs vaginais de vacas leiteiras no d0 e d3, quando comparados com d-7 e d7 ( $\mathrm{P}<0,05$; Gráfíco 2A). O aumento na quantidade de animais com a presença dessa bactéria na vagina, no momento do parto/pós-parto é explicado pelo fato de ocorrer contaminação do sistema genital da fêmea no momento do parto e, posteriormente, ocorre a fixação e proliferação desses microrganismos no lúmen uterino (ELLITOT et al., 1968; BEKANA; KINDAL, 1996). Segundo Sheldon et al., (2008), esse agente é comumente associado com metrite, endometrite e piometra. A diminuição significativa de animais com $E$ coli na vagina no d7, pode estar associado ao tratamento das enfermidades uterinas do pós parto imediato (RP e metrite). $\mathrm{O}$ uso de ceftiofur em dosagem de $1 \mathrm{mg} / \mathrm{kg}$ de peso vivo, por 3 a 5 dias resulta em altas concentrações desse fármaco nos tecidos uterinos, atingindo uma eficácia $>90 \%$, contra a $E$. coli, F. necrophorum e T. pyogenes (DRILLICH et al., 2006; SHELDON et al., 2004), os principais agentes causadores de metrite.

Gráfico 1- (A,B e C) Progressão da microbiota vaginal. Streptococcus spp. letra (A), E.coli (B), Staphylococcus, (C), letras diferentes correspondem diferenças significativas. 

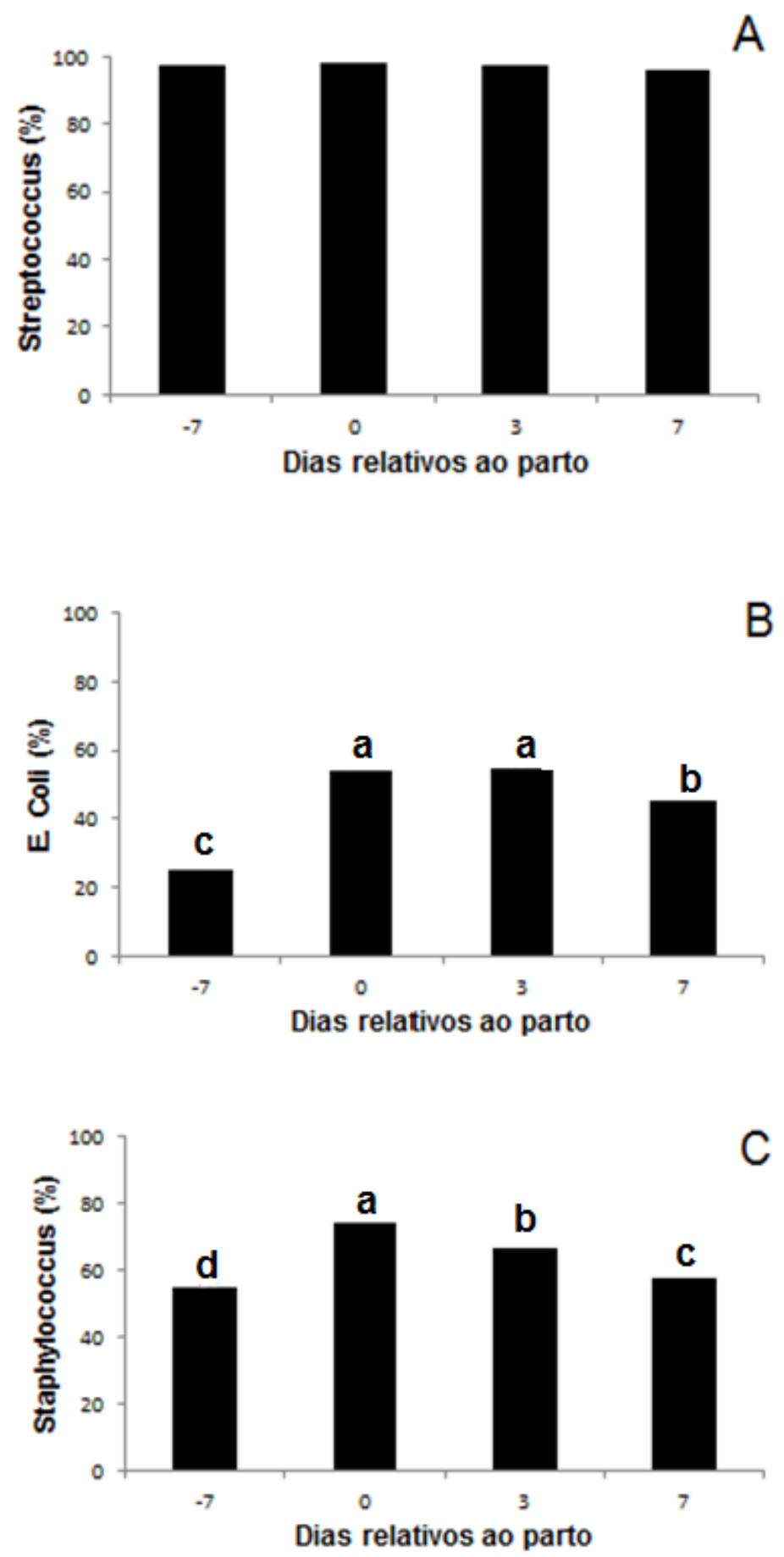

Vacas que tiveram metrite apresentaram maior crescimento bacteriano no meio de cultura para $E$ coli no d3 após o parto, maior risco de desenvolver metrite ( $\mathrm{P}=0.0018$; Tabela 3), semelhante ao resultado encontrado por Wang et al (2013), onde esse microrganismo foi isolado, em vacas leiteiras acometidas por metrite no pós parto, utilizando a técnica de amplificação do DNA 16S. 
Vacas com RP apresentaram maior crescimento bacteriano nos $\mathrm{d} 3 \mathrm{e} \mathrm{d} 7$, quando comparadas com vacas que não retiveram a placenta ( $\mathrm{P}<0.05$; Tabela 4). Salvador (2014) relatou que a retenção de placenta significa a permanência dos restos placentários no útero da vaca por mais de 12 horas depois do parto. Se a vaca não expulsar esses restos, eles vão servir como um meio de cultura, para o crescimento de bactérias patogênicas, capazes de provocar uma infecção grave no útero. Resultado semelhante foi encontrado por Dohmen et al (2000), onde o lóquia, presente no útero após o parto, propicia um meio ideal de crescimento e multiplicação da Echerichia coli, resultando na liberação de endotoxinas, como lipopolissacarídeos (LPA), que favorecem o desenvolvimento de futuras infecções uterinas provocadas por T. pyogenes e outras bactérias Gram-negativas, principalmente se precedida de RP ou distocia (DOHMEN et al, 2000).

Tabela 3 - Crescimento da E. coli do meio de cultura detectada em amostras vaginais em vacas leiteiras, diagnosticadas com RP e metrite, comparada com as vacas saudáveis no $d-7,0,3$, e 7 dias relativo ao parto (DRP). $* \mathrm{P}<0.05, * * \mathrm{P}<0.01 \mathrm{e} * * * \mathrm{P}<0.01$

\begin{tabular}{|c|c|c|c|c|c|c|c|c|}
\hline \multirow[b]{2}{*}{ DRP } & \multicolumn{4}{|c|}{$\mathrm{RP}$} & \multicolumn{4}{|c|}{ METRITE } \\
\hline & & Sim & $\mathrm{P}$ & OR & Não & Sim & $\mathrm{P}$ & OR \\
\hline-7 & $3.30 \%$ & $5.70 \%$ & 0.212 & 1.76 & $3.30 \%$ & $5.70 \%$ & 0.7 & 0.532 \\
\hline 0 & $2.50 \%$ & $4.83 \%$ & 0.272 & 1.95 & $2.50 \%$ & $4.83 \%$ & 0.291 & 1.64 \\
\hline 3 & $0 \%$ & $7.18 \%$ & $0.0241^{*}$ & 10.6 & $7 \%$ & $28.50 \%$ & $0.0018 * *$ & 5.3 \\
\hline 7 & 0.06 & $6.80 \%$ & $0.0206 *$ & 11.6 & $14.60 \%$ & $20.70 \%$ & 0.347 & 1,5 \\
\hline
\end{tabular}

Vacas que apresentaram distocia tiveram maior risco de apresentar E coli no meio de cultura, no parto e no pós o parto, quando comparados com vacas saudáveis. Da mesma forma, vacas que apresentaram partos gemelares também apresentaram significativamente maior risco de apresentar o crescimento de $E$ coli no d3 após o parto ( $\mathrm{P}=0.0018$; Tabela 4). Isso se deve ao trauma tecidual que ocorre nas intervenções obstétricas, favorecendo o desenvolvimento, penetração e fixação de bactérias patogênicas no lúmen uterino, no momento do parto e pós parto, inicialmente causado por E. coli e, posteriormente, Fusobacteria e Bacteroidetete (KANEENE E MILLER, 1994; DUBUC et al., 2010; BICALHO et al, 2012). 
Tabela 4 - Crescimento da E. coli do meio de cultura detectada em amostras vaginais em vacas leiteiras, diagnosticadas com Distocia e Gêmeos, comparada com as vacas saudáveis no d -7,0, 3, e 7 dias relativo ao parto (DRP). $* \mathrm{P}<0.05, * * \mathrm{P}<0.01 \mathrm{e} * * * \mathrm{P}<0.01$.

\begin{tabular}{|c|c|c|c|c|c|c|c|c|}
\hline \multirow[b]{2}{*}{ DRP } & \multicolumn{4}{|c|}{ DISTOCIA } & \multicolumn{4}{|c|}{ GÊMEOS } \\
\hline & Não & Sim & $\mathrm{P}$ & OR & Não & Sim & $\mathrm{P}$ & OR \\
\hline-7 & $16,1 \%$ & $13.04 \%$ & 0.382 & 0.78 & $3.30 \%$ & $5.70 \%$ & 0.7 & 0.532 \\
\hline 0 & $10.12 \%$ & $18.81 \%$ & $0.0258 *$ & 2.05 & $2.50 \%$ & $4.83 \%$ & 0.291 & 1.64 \\
\hline 3 & $6.52 \%$ & $17.96 \%$ & $0.0041 * *$ & 3.14 & $7 \%$ & $28.50 \%$ & $0.0018 * *$ & 5.3 \\
\hline 7 & $6.91 \%$ & $19.84 \%$ & $0.00161 * *$ & 3.33 & $14.60 \%$ & $20.70 \%$ & 0.347 & 1,5 \\
\hline
\end{tabular}

Tabela 5 - Crescimento da E. coli do meio de cultura detectadas em amostras vaginais em vacas leiteiras, diagnosticadas com Aborto e Natimortos, comparadas com as vacas saudáveis no d-7,0, 3, e 7 dias relativos ao parto (DRP) $* \mathrm{P}<0.05, * * \mathrm{P}<0.01$ e $* * * \mathrm{P}<0.01$

\begin{tabular}{|c|c|c|c|c|c|c|c|c|}
\hline \multirow[b]{2}{*}{ DRP } & \multicolumn{4}{|c|}{ ABORTO } & \multicolumn{4}{|c|}{ NATIMORTOS } \\
\hline & Não & Sim & $P$ & OR & Não & Sim & $\mathrm{P}$ & OR \\
\hline-7 & $4.57 \%$ & $2.90 \%$ & 0.396 & 0.62 & $5.54 \%$ & $3.62 \%$ & 0.377 & 0.64 \\
\hline 0 & $3.79 \%$ & $5.90 \%$ & 0.37 & 1.6 & $2.53 \%$ & $6.99 \%$ & 0.0681 & 2.89 \\
\hline 3 & $2.89 \%$ & $7.18 \%$ & 0.106 & 2.6 & $2.17 \%$ & $5.38 \%$ & 0.164 & 2.56 \\
\hline 7 & $5.66 \%$ & $3.81 \%$ & 0.469 & 0.66 & $2.51 \%$ & $5.34 \%$ & 0.22 & 2.18 \\
\hline
\end{tabular}

Aborto e natimortos não foram fator de risco para o crescimento de $E$ coli no meio de culltura ( $\mathrm{P}>0,05$; Tabela 5), no parto e pós parto, porém, as vacas que tiveram bezerros natimortos, tiveram aproximadamente o dobro de chance de apresentar crescimento de E Coli, no parto e pós parto (Tabela 5). Esse resultado difere dos encontrados por Linden et al., (2009), onde natimortos e bezerros machos foram associados a um aumento de bactérias patogênicas e incidência de doenças uterinas. Segundo Willians et al., (2005), numericamente o patógeno com maior pevalência foi $E$. coli (37\% das bactérias isoladas no pós parto)

Tabela 6 - Crescimento da E. coli do meio de cultura de dectada em amostras vaginais em vacas leiteiras, diagnosticadas com Febre, comparadas com as vacas saudáveis no $\mathrm{d}-7,0,3$, e 7 relativa ao parto. $* \mathrm{P}<0.05$, **P $<0.01 \mathrm{e}^{* * *} \mathrm{P}<0.01$. 


\begin{tabular}{ccccc}
\hline & \multicolumn{4}{c}{ FEBRE } \\
\cline { 2 - 5 } DRP & Não & Sim & \multicolumn{1}{c}{$P$} & OR \\
\cline { 2 - 5 }-7 & 13.4 & 39.6 & 0.0827 & 3.0 \\
0 & 44.5 & 32.7 & 0.573 & 0.72 \\
3 & 12.7 & 22.2 & $0.0377 *$ & 1.9 \\
7 & 9.5 & 17.7 & $0.0468 *$ & 2.04 \\
\hline
\end{tabular}

Febre foi fator de risco para o crescimento de Echerichiacoli no meio de culltura pós parto (Tabela 6). Nas infecções com características de extrema severidade, como são os casos de metrite puerperal tóxica/séptica, causadas/precedidas por Echerichia.coli, e associada à Fusobacteria e Bacteriodetes, os animais apresentam um agravamento da sintomatologia sistêmica, provocada pela toxemia e febre.

Nos animais com estes tipos de infecções, os sintomas tendem a surgir entre um a cinco dias após o parto, podendo evoluir sinais de peritonite e a adoção de uma posição arqueada, com elevada relutância ao movimento, principalmente ao se levantarem quando em decúbito (HILLMAN \& GILBERT, 2008). Mesmo que a antibioticoterapia seja instituída rapidamente, o resultado da cura de maneira geral é positivo e o tipo de antibiótico utilizado parece não ser decisivo (Penicilina, oxiteracicilina ou ceftiofur) (Smith et al. 1998). Entretanto, o desaparecimento de febre leva por volta de 5 dias, o que explica porque animais, que estão sendo tratados para doenças uterinas, ainda apresentam febre no dia 7. Os resultados desse estudo são semelhantes aos encontrados por Santos e Bicalho (2012), onde os filos associados à Echerirchiacoli (Fusobacteria, Proteobacteria, e Bacteriodetes), foram relacionados com febre pós-parto e doenças uterinas.

Tabela 7- Crescimento da E. coli do meio de cultura detectado em amostras vaginais em vacas leiteiras, diagnosticadas Cíclicas, comparadas com as vacas saudáveis no $\mathrm{d}-7,0,3$, e 7 relativo aos dias após o parto. $* \mathrm{P}<0.05, * * \mathrm{P}<0.01 \mathrm{e} * * * \mathrm{P}<0.01$

\begin{tabular}{ccccc}
\hline \multicolumn{4}{c}{ CICLICIDADE } \\
\cline { 2 - 5 } Não & \multicolumn{1}{c}{$\operatorname{Sim}$} & $\mathrm{P}$ & $\mathrm{OR}$ \\
\cline { 2 - 5 } $47.10 \%$ & $59.01 \%$ & 0.318 & 1.62 \\
$48 \%$ & $48 \%$ & 0.981 & 1 \\
$54.10 \%$ & $48.90 \%$ & 0.675 & 0.8 \\
$50 \%$ & $45 \%$ & 0.611 & 0.8 \\
\hline
\end{tabular}


Não houve diferença na ciclicidade em vacas que apresentaram crescimento bacteriano, no pré e pós-parto (Tabela 5), quando comparadas com fêmeas saudáveis. E coli é o agente patogênico Gram-negativo comumente associado à metrite e mastite, e grande parte da patogenicidade, está associada ao lipopolissacarídeo de endotoxina bacteriana (LPS). Existe uma ligação entre infecção bacteriana, disfunção ovariana e acúmulo de LPS no líquido folicular, de animais com metrite in vivo, Herath et al (2007). Além disso, o estradiol tem sua concentração reduzida, em células da granulosa, cultivadas com LPS, suprimindo a liberação hipotalâmica de GnRH , a secreção hipofisária de hormônio luteinizante ( LH ), o que causa alterações na ciclicidade e leva a uma menor propensão à ovulação (Williams et al 2008). Contrariando esses resultados, Gilbert (2015) sugere que fatores nutricionais e genéticos favorecem ao retorno rápido à ciclicidade em vacas leiteiras.

Houve diferença estatítistica no crescimento de colônias bacterianas de Sthaphyloccus spp. em todos os dias referentes ao parto, quando comparado com os dias -7,0,3 e 7 relativos ao parto.t, para no $(\mathrm{P}<0,05)$. Houve um aumento significativo de vacas com crescimento para Sthaphyloccus spp. no pós parto, o que pode ser explicado pelas contaminação do lúmen uterino, a grande maioria das vacas no parto e nas primeiras duas semanas após o parto (ELLITOT et al., 1968; BEKANA; KINDAL, 1996). Crescimento bacteriano de Sthaphyloccus spp. não foi fator de risco para nenhuma das variáveis de doença e doença uterina avaliadas para E. coli.. Os resultados encontrados na literatura associando Sthaphyloccus spp. com doenças uterinas são conflitantes. Sheldon et al., (2002), descreveram que metrite causada por Staphylococcus aureus, pode levar a quadro septicêmico e acometimento de vários órgãos, como sistema nervoso central, trato gastrointestinal, baço, rins, pulmões e musculatura esquelética de todo o corpo. Já estudos realizados por Oliveira 1995relata que Sthaphyloccus spp são considerados habitantes da microbiota da vulva, vagina, pele e trato gastrintestinal, e não possuem relação com doenças uterinas (OLIVEIRA 1995). 


\section{CONCLUSÕES}

Os resultados do estudo 1 sugerem que, a composição bacteriana (microbiota) e CBT diferiram entre vacas de saúde e vacas que foram diagnosticados com doenças uterinas (RP, metrite e CE), aceitando a hipótese inicial. Fatores de risco conhecidos de doenças uterinas como distocia, gêmelares, e a paridade foram associadas ao aumento da CBT vaginal. Novamente, foi relatada a importância do gênero Fusobacteria, Proteobacteriae Bacteroidetes, associados infecções uterinas e febre. Foram encontrados em amostras de swabs vaginais, dois novos gêneros que até então eram relacionados ao sitema respiratório de vacas leiteiras: Gallibacterium e Mannheimia. Além disso, os resultados obtidos neste artigo sugerem que a PCR em tempo real pode ser um método preciso e prático para estudar mudanças quantitativas e qualitativas do microbioma bovino, esta informação pode ser aplicada para determinar a CBT em amostras clínicas derivadas dos tractos reprodutivos de vacas leiteiras onde a contagem de colônias, historicamente, era a primeira opção.

Os resultados do estudo 2 sugerem que vacas que apresentam E. coli nas amostra de swabs vaginais, tiveram maior incidência de distúrbios ligados a doenças uterinas. Fatores de risco como cetose e retenção de placenta foram associados com vacas que apresentaram metrite. A retenção de placenta mais uma vez se confirmou como um fator de risco para mastite e cetose. O meio de cultura Accumaster®, utilizado na rotina das fazendas para diagnóstico de bactérias que se desenvolvem em vacas com mastite, é um método prático, rápido e barato, que pode ser realizado dentro da fazenda por funcionários treinados para identificar vacas com E Coli no pós parto imediato, aceitando a hipótese inicial. 


\section{REFERÊNCIAS}

AGARWAL. A.; APONTE-MELLADO, A.; PREMKUMAR, B. J.; SHAMAN, A.; GUPTA, S. The effects of oxidative stress on female reproduction: a review. Reproductive Biology and Endocrinology, v. 10, p. 49, 2012. (doi:10.1186/1477- 7827-10-49).

AMOS, C. M. R., G. D. ; HEALEY, R. J.; GOLDSTONE, S. M. ;MAHAN, A. ;DUVEL, H. J. ;SCHUBERTH, O. ;SANDRA, P. ;ZIEGER, I. ;DIEUZY-LABAYE, D. G.; SMITH and I. M. SHELDON. Differential endometrial cell sensitivity to a cholesterol-dependent cytolysin links Trueperella pyogenes to uterine disease in cattle. Biology Reproduction, v. 90, p.54, 2014.

AZAWI, O. I.; OMRAN, S. N. \& HADAD, J. J. Clinical, bacteriological, and histopathological study of toxic puerperal metritis in Iraqi Buffalo. Journal of Dairy Science. v.90, p. 4654-466, 2007.

AZAWI, O; ALI J.; LAZIM J. Pathological and anatomical abnormalities affecting buffalo cows reproductive tracts in Mosul Iraqi Journal Veteranary Science, v.22 ,p. 59-67, 2008.

BELL, A. W. Regulation of organic nutrient metabolism during transition from late pregnancy to early lactation. Journal Dairy Science. v.73, p.2804-2819, 1995.

BEKANA M, JONSSON P, KINDAHL H. Intrauterine bacterial findings and hormonal profiles in post-partum cows with normal puerperium. Acta Veterinary Scandinava, v..37, p.251-63, 1996.

BENZAQUEN, M. E., C. A. RISCO, L. F. ARCHBALD, P. MELENDEZ, M. J. THATCHER AND W. W. THATCHER. Rectal temperature, calving-related factors, and the incidence of puerperal metritis in postpartum dairy cows. Journal Dairy Science. v.90, p.2804-2814, 2007. 
BICALHO, R. C., K. N. GALVAO, S. H. CHEONG, R. O. GILBERT, L. D. WAR- NICK, and C. L. GUARD. Effect of stillbirths on dam survival and reproduction performance in Holstein dairy cows. Journal Dairy Science. V.90, p.2797-2803, 2007.

BICALHO, R. C., V. S. MACHADO, M. L. BICALHO, R. O. GILBERT, A. G. TEIXEIRA, L. S. CAIXETA, and R. V. PEREIRA. Molecular and epidemiological characterization of bovine intrauterine Escherichia coli. Journal Dairy Science V.93, p.5818-5830. 2010.

BICALHO, M. L., V. S. MACHADO, G. OIKONOMOU, R. O. GILBERT AND R. C. BICALHO. Association between virulence factors of Escherichia coli, Fusobacterium necrophorum, and Arcanobacterium pyogenes and uterine diseases of dairy cows. Veterinary Microbiology. v.157, p.125-131. 2012.

BISGAARD, M. Ecology and significance of Pasteurellaceae in ani- mals. Zentralbl. Bacteriology. v.279, p.7-26. 1993.

BENCHARIF, D.; TAINTURIER, D.; SLAMA, H.; BRUYAS, J. F.; BATTUT, I. \& FIENI, F..Prostaglandines et post-partum chez la vache. Revue de Médecine Vétérinaire. v.151(5),p. 401-408, 2000.

BONNETT, B. N., S. W. MARTIN, V. P. GANNON, R. B. MILlER AND W. G. ETHERINGTON. Endometrial biopsy in holstein-friesian dairy cows. III. bacteriological analysis and correlations with histological findings. Canadian Journal of Veterinary Research. J. Vet. Res. V.55, p.168-173. 1991.

BONDURANT, 1999 R.H. Bondurant Inflammation in the bovine female reproductive tract Journal Animal Science., v.77, (Suppl. 2) p. 101-110,1999.

BORSBERRY S, DOBSON H. Periparturient diseases and their effect on reproductive performance in five dairy herds. Veterinary Record; v.124, p.217-9. 1989. 
CAPORASO, J. G., C. L. LAUBER, W. A. WALTERS, D. BERG-LYONS, J. HUNTLEY, N. FIERER, S. M. OWENS, J. BETLEY, L. FRASER, M. BAUER, N. GORMLEY, J. A. GILBERT, G. SMITH, AND R. KNIGHT.. Ultrahigh-throughput microbial community analysis on the Illumina HiSeq and MiSeq platforms. ISME Journal. V.6, p.1621-1624. 2012

CAI TQ, WESTON PG, LUND LA, BRODIE B, MCKENNA DJ, WAGNER WC. Association between neutrophil functions and periparturient disorders in cows. American Journal of Veterinary, v.55, p.934-943. 1994.

CARTER, G. R., D. J. WISE AND G. R. CARTER. Essentials of Veterinary Bacteriology and Mycology. 6th ed. Iowa State Press, Ames, Iowa

CHEONG, S. H., D. V. NYDAM, K. N. GALVÃO, B. M. CROSIER AND R. O. GILBERT. 2011. Cow-level and herd-level risk factors for subclinical endometritis in lactating Holstein cows. Journal Dairy Science. v.94, p.762-770. 2004.

CHEONG, S. H., NYDAM, D. V., GALVAO, K. N., CROSIER, B. M., RICCI, A., CAIXETA, L. S., SPER, R. B., FRAGA, M., GILBERT, R. O., Use of reagent test strips for diagnosis of endometritis in dairy cows. Theriogenology, v. 77, p.858-864. 2012.

COLLIER, R. J., G. E. DAHL AND M. J. VANBAALE. Major advances associated with environmental effects on dairy cattle. Journal Dairy Science. v.89, p.1244-1253. 2006.

DHAKAL, K., C. MALTECCA, J. P. CASSADY, G. BALOCHE, C. M. WILLIAMS, AND S. P. WASHBURN. Calf birth weight, gestation length, calving ease, and neonatal calf mortality in Holstein, Jersey, and crossbred cows in a pasture system. Journal Dairy Science. v.96, p.690-698. 2013

DOHOO I, MARTIN W, AND STRYHN H. Screening and diagnostic tests. In: Veterinary Epidemiologic Research. Charlottetown: VER Inc;. p. 91-134. 2009 
DRACKLEY, J.K.,. ADSA Foundation Scholar Award. Biology of dairy cows during the transition period: the final frontier Journal of Dairy Science v.82, p.2259- 2273. 1999.

DRILliCH, M., O. BEETZ, A. PFUTZNER, M. SABIN, H. J. SABIN, P. KUTZER, H. NATTERMANN, W.HEUWIESER. Evaluation of a systemic antibiotic treatment of toxic puerperal metritis in dairy cows. Journal Dairy Science. v.84, p.2010-2017. 2001.

DRILLICH, M. An update on uterine infections in dairy cattle. Slovenian Veterinary Research. V.43, n.1, p.11-15. 2006.

DUBOIS, P. R. AND D. J. WILLIAMS. Increased incidence of retained placenta associated with heat stress in dairy cows. Theriogenology. V.13, p.115-121.1980

EDMONSON, A. J.; LEAN, I. J.; WEAVER, L. D.; FARVER, T.; WEBSTER, G. A body condition scoring chart for Holstein dairy cows. Journal of Dairy Science, v. 72, n. 1, p. 6878, 1989.

ELLIOT L, MCMAHON KJ, GIER HT, MARION GB. Uterus of the cow after parturition: bacterial content. Am J Vet Res;v.29, p.77-81. 1968.

EMERICK, L. L.; DIAS, J. C.; GONÇALVES, P. E. M.; MARTINS, J. A. M.; SOUZA, F. A.; VALE FILHO, V.R. \& ANDRADE, V. J. (2009). Retorno da actividade ovariana luteal cíclica de vacasde corte no pós-parto: uma revisão. Revista Brasileira Reprodução Animal. V.33, n.4, p.203-212.

DEJARNETTE, J. M.; SATTLER, C. G.; MARSHALL, C. E. et al. Voluntary waiting period management practices in dairy herds participating in a progeny test program. Journal Dairy Science., v. 90, p.1073-1079, 2007.

DE VRIES, A. Economics of the voluntary waiting period and value of a pregnant. In: DAIRY CATTLE REPRODUCTIVE CONFERENCE DENVER, 2007, Denver. Anais... Denver: CO,. p. 1-10. 2007 
DOHMEN MJW, LOHUIS JACM, HUSZENICZA G, NAGY P, GACS M. The relationship between bacteriological and clinical findings in cows with subacute/chronic endometritis. Theriogenology. v. 43, p.1379-1388. 1995.

DOHMEN, M. J., K. JOOP, A. STURK, P. E. BOLS AND J. A. LOHUIS. Relationship between intra-uterine bacterial contamination, endotoxin levels and the development of endometritis in postpartum cows with dystocia or retained placenta. Theriogenology. v.54, p.1019-1032.2000.

DUBUC, J., T. F. DUFFIELD, K. E. LESLIE, J. S. WALTON, AND S. J. LEBLANC.. Definitions and diagnosis of postpartum endometritis in dairy cows. Journal Dairy Science v.93, p.5225-5234. 2010a

DUBUC, J., T. F. DUFFIELD, K. E. LESLIE, J. S. WALTON AND S. J. LEBLANC.. Risk factors for postpartum uterine diseases in dairy cows. Journal Dairy Science. n.93, p.57645771. $2010 \mathrm{~b}$

FÖLDI, J.; KULCSÁR, M.; PÉCSI, A.; HUYGHE, B.; DE SA, C.; LOHUIS, J. A. C. M.; COX, P. \& HUSZENICZA, G. Bacterial complications of postpartum uterine involution in cattle. Animal Reproduction Science. n.96,p. 265-281. 2006

FRICKE, P. M., D. Z. CARAVIELLO, K. A. WEIGEL, AND M. L. WELLE. Fertility of dairy cows after resynchronization of ovulation at three intervals following first timed insemination. Journal Dairy Science. n.86, p.3941-3950. 2003

GARCÍA, M. E.; QUINTELA, L. A.; TABOADA, M. J.; ALONSO, G.; VARELA-PORTAS, B.; DÍAZ, C.; BARRIO, M.; BECERRA, J. J.; PEÑA, A. I.; DEIROS, J. \& HERRADÓN, P. G. Risk factors for metritis in dairy cows: A retrospective study in the north west of Spain. Archivos Zootecnia. V.53, p.383-386. 2004.

GALVÃO, K. N., M. FRAJBLAT, S. B. BRITTIN, W. R. BUTLER, C. L. GUARD, AND R. O. Postpartum uterine diseases in dairy cows. Animal Reproduction, v.9, p.290-296. 2012. 
GAUTAM G, NAKAO T, KOIKE K, LONG ST, YUSUF M, RANASINGHE RMSBK, HAYASHI A. Spontaneous recovery or persistence of postpartum endometritis and risk factors for its persistence in Holstein cows. Theriogenology, v.73, p.168-179, 2010.

GILBERT , R. O. Bovine endometritis: the burden of proof. Cornell Vet. v.82, p.11-4. 1992.

GILBERT, R.O., Y.T. GRÖHN, P.M. MILLER, AND D.J. HOFFMAN. "Effect of Parity on Periparturient Neutrophil Function in Dairy Cows." Veterinary Immunology and Immunopathologyet. V.36, p.75-82. 1993.

GILBERT, R.O.; YANG, X.; JIANG, S.; SCHLAFER, D.H.; SALUSTE, V., SCHEYTT, A. Effects of aseptic inflammation on development of bovine embryos in vivo and in vitro. In: Proceedings of the Annual Meeting of the Society for Theriogenology;. p.312. 1995

GILBERT, R. O. Uterine disease in the postpartum period. In: Proceedings of the 15th International Congress on animal reproduction;. p. 66-73. 2004

GILBERT, R. O., S. T. SHIN, C.L. GUARD, H. N. ERB, AND M. FRAJBLAT.. Incidence of endometritis and its effects on reproductive performance of dairy cows. Theriogenology v.64, p.1879-1888. 2005.

GILBERT, R. O. Effect of prostaglandin F2 $\alpha$ on subclinical endometritis and fertility in dairy cows. Journal Dairy Science. v.92, p.4906-4913.2009.

GIULIODORI, M. J., R. P. MAGNASCO, D. BECU-VILLALOBOS, I. M. LACAUMENGIDO, C. A. RISCO AND R. L. DE LA SOTA.. Metritis in dairy cows: Risk factors and reproductive performance. Journal Dairy Science. v.96, p.3621-3631. 2013

GOFF, J.P.; HORST, R.L. Physiological changes at parturition and their relationship to metabolic disorders. Journal Dairy Science, v.80, p.1260-1268. 1997. 
GOFF, J. P., K. KIMURA AND R. L. HORST.. Effect of mastectomy on milk fever, energy, and vitamins A, E, and beta-carotene status at parturition. Journal Dairy Science. v.85, p.1427-1436. 2002.

GRUMMER, R. R. Impact of changes in organic nutrients metabolism on feeding the transition cow. Journal of Animal Science, v.73, p.2820-2833, 1995.

HAFEZ, E. S. E. \& HAFEZ, B. Anatomia da reprodução feminina. In Hafez, E. S. E. \& Hafez, B, Reprodução Animal, 7ª ed. , p 13-29. São Paulo: Manole, 2004.

HAMMON, D. S.; EVJEN, I. M.; DHIMAN, T. R.; GOFF, J. P.; WALTERS, J. L. Neutrophil function and energy status in Holstein cows with uterine health disorders. Vet Immunol Immunopathol, v.113, p.21-29. 2006

HARRISON, J. H.; HANCOCK, D. D,; ST PIERRE, N.; CONRAD, H. R.; HARVEY W. R. Effect of prepartum selenium treatment on uterine involution in the dairy cow. Journal Dairy Science, v.69, p.1421-1425.1986.

HANSEN PJ, SOTO P, NATZKE RP. Mastitis and fertility in cattle-possible involvement of inflammation or immune activation in embryonic mortality. American Journal of Reproductive Immunologym J Reprod Immunol. v.51, p.294-301. 2004

HATAMOTO, L. K. Efeito do Estresse e da Suplementação com Vitamina E Sobre Parâmetros Espermáticos, Peroxidação Lipídica de Componentes Seminais e Atividade das Enzimas Antioxidantes Presentes no Plasma Seminal de Cães. 2004, 180 f. Tese- Faculdade de Medicina Veterinária e Zootecnia, Universidade de São Paulo, São Paulo, 2004.

HERATH S.; WILLIAMS EJ.; LILLY ST,; GILBERT RO.; DOBSON H, BRYANT CE.; SHELDON IM. Ovarian follicular cells have innate immune capabilities that modulate their endocrine function. Reproduction 2007; 134:683-693 
HEUER, C.; SCHUKKEN, Y. H., DOBBELAAR, P. Postpartum body condition score and results from the first test day Milk as predictors of disease, fertility, yield, and culling in commercial dairy herds. Journal Dairy Science; v.82, p.295-304. 1999

HILLMAN, R. \& GILBERT, R. O. Reproductive Diseases. In: T. J. Divers \& S. F. Peek, Rehbun's Diseases of Dairy Cattle, 2th ed, p 395-446. China: Saunders Elsevier. 2008.

HUSZENICZA, G., M. FODOR, M. GACS, M. KULCSAR, M. J. W. DOHMEN, M. VAMOS, L. PORKOLAB, T. KEGL, J. BARTYIK, J. A. C. M. LOHUIS, S. JANOSI, AND G. SZITA.. Uterine bacteriology, resumption of cyclic ovarian activity and fertility in postpartum cows kept in large-scale dairy herds. Reproduction Domestic Animals. V.34, p.237-245. 1999.

HUZZEY, J. M., D. M. VEIRA, D. M. WEARY AND M. A. G. VON KEYSERLINGK.. Prepartum behavior and dry matter intake identify dairy cows at risk for metritis. Journal Dairy Science 90:3220-3233. 2007.

JEON, S. J., A. VIEIRA-NETO, M. GOBIKRUSHANTH, R. DAETZ, R. D. MIN- GOTI, A. C. PARIZE, S. L. DE FREITAS, A. N. DA COSTA, R. C. BICAlHO, S. LiMA, K. C. JEONG, AND K. N. GALVAO. Uterine microbiota progression from calving until establishment of metritis in dairy cows. Applied and Environmental Microbiology. V.81, p.6324-6332. Johanson. 2015.

JOST, B. H. AND S. J. BILLINGTON. Arcanobacterium pyogenes: Molecular pathogenesis of an animal opportunist. Antonie Van Leeuwenhoek. V.88, p.87-102. 2005.

KANEENE, J. B. AND R. MILLEr. Risk factors for metritis in Michigan dairy cattle using herd- and cow-based modelling approaches. Preventive Veterinary Medicine. v.23, p.183200. 1995.

KASIMANICKAM R， DUFFIELD TF， FOSTER RA， GARTLEY CJ, LESLIE KE,WALTON JS, ET AL. Endometrial cytology and ultrasonography for the detection of subclinical endometritis in postpartum dairy cows. Theriogenology; n.62, p.9-23. 2004. 
KASIMANICKAM R, DUFFIELD TF, FOSTER RA, GARTLEY CJ, LESLIE KE, WALTON JS, ET AL. The effect of a single administration of cephapirin or cloprostenol on the reproductive performance of dairy cows with subclinical endometritis. Theriogenology; n.63, p.818-30. 2005.

KEHRLI ME, JR., GOFF JP. Periparturient hypocalcemia in cows: effects on peripheral blood neutrophil and lymphocyte function. Journal of Dairy Science. v.72, n.5, p.:11881196. 1989.

KIMURA, K.; GOFF, J. P.; KEHRLI, M. E.; REINHARDT, T. A. Decreased neutrophil function as a cause of retained placenta in dairy cattle. Journal Dairy Science, v. 85, p. 544$550,2002$.

KIMURA, K., T. A. REINHARDT AND J. P. GOFF. Parturition and hypocalcemia blunts calcium signals in immune cells of dairy cattle. Journal Dairy Science. V.89, p.2588-2595. 2006.

KIRAKOFE, G. H. (1980). Uterine involution: its role in regulating postpartum intervals. Journal Dairy Science. 51(1), 16-28.

KOZICKI, L. E. Aspectos fisiológicos e patológicos do puerpério em bovinos. Archives of Veterinary Science. v.3, n.1, p.9-19. 1998.

LAGO A, GODDEN SM, BEY R, RUEGG PL, LESLIE K. The selective treatment of clinical mastitis based on on-farm culture results: I. Effects on antibiotic use, milk withholding time, and short-term clinical and bacteriological outcomes. Journal of Dairy Science.; v.94, n.9, p.:4441-56. 2011a

LAGUARDIA-NASCIMENTO, M., K. M. BRANCO, M. R. GASPARINI, S. GIANNATTASIO-FERRAZ, L. R. LEITE, F. M. ARAUJO, A. C. SALIM, J. R. NICOLI, G. C. DE OLIVEIRA, AND E. F. BARBOSA-STANCIOLi.. Vagi- nal microbiome characterization of Nellore cattle using metage- nomic analysis. PLoS One v.10, p.294. 2015. 
LAGO A, GODDEN SM, BEY R, RUEGG PL, LESLIE K. The selective treatment of clinical mastitis based on on-farm culture results: II. Effects on lactation performance, including clinical mastitis recurrence, somatic cell count, milk production, and cow survival. Journal Dairy Science.; v.94, n.9, p.4457-67. 2011

LEBLANC SJ, DUFFIELD TF, LESLIE KE, BATEMAN KG, KEEFE GP, WALTON JS, ET AL. Defining and diagnosing postpartumclinical endometritis and its impact on reproductive performance in dairy cows. Journal Dairy Science; v.85, p.2223-36. 2002

LEBLANC, S. J., T. F. DUFFIELD, K. E. LESLIE, K. G. BATEMAN, G. P. KEEFE, J. S. WALTON, AND W. H. JOHNSON. Defining and diagnosing postpartum clinical endometritis and its impact on reproductive performance in dairy cows. Journal Dairy Science. 85:2223-2236. 2002a.

LEBLANC, S. J.. Postpartum uterine disease and dairy herd reproductive performance: A review. Veterinary Journal. v.176, p.102-114. 2008.

LEBLANC, S. J., T. OSAWA AND J. DUBUC.. Reproductive tract defense and disease in postpartum dairy cows. Theriogenology. V.76, p.1610-1618. 2011

LESLIE, K. E. The events of normal and abnormal postpartum reproductive endocrinology and uterine involution in dairy cows: a review. Canadian Veterinary Journal. V.24, n.3, p.67-71. 1983.

LINDEN, T. C., R. C. BICALHO, AND D. V. NYDAM.. Calf birth weight and its association with calf and cow survivability, dis- ease incidence, reproductive performance, and milk production. Journal Dairy Science. v.92, p.2580-2588. 2009.

LEWIS, G. S.. Uterine health disorders. Journal Dairy Science. v.80, p.984-994. 1997.

LIMA, F. S., A. VIEIRA-NETO, G. S. VASCONCELlOS, R. D. MINGOTI, E. KARAKAYA, E. SOLE, R. S. BISINOTTO, N. MARTINEZ, C. A. RISCO, K. N. GALVAO AND J. E. SANTOS. Efficacy of ampicillin trihydrate or ceftiofur hydrochloride for treatment 
of metritis and subsequent fertility in dairy cows Journal Dairy Science. v.97, p.5401-5414. 2014.

LIMA, S. F., A. G. TEIXEIRA, C. H. HIGGINS, F. S. LIMA, AND R. C. BICALHO. The upper respiratory tract microbiome and its potential role in bovine respiratory disease and otitis media. Science Reproduction. v.6, p.29050. 2016.

LOCATELLI C, SCACCABAROZZI L, PISONI G, BRONZO V, CASULA A, TESTA F, ALLODI S, POLLERA C, TONI F, MORONI P.. Helcococcuskunzii and Helcococcusovis isolated in dairy cows with puerperal metritis. The Journal of General and Applied Microbiology. v.59, p.371-374. 2013.

MACHADO VS, BICALHO ML, PEREIRA RV, CAIXETA LS, BITTAR JH, OIKONOMOU G, GILBERT RO, BICALHO RC. The effect of intrauterine administration of mannose or bacteriophage on uterine health and fertility of dairy cows with special focus on Escherichia coli and Arcanobacterium pyogenes Journal Dairy Science.;v.95, n.6, p.:3100-9. 2012 Jun

MALINOWSKI, E.; LASSA, H.; MARKIEWICZ, H.; KAPTUR, M.; NADOLNY, M.; NIEWITECKI, W. \& ZIETARA, J. Antimicrobial resistance of aerobic bacteria isolated from the inflamed uterus of cows. Medycyna Weterynaryjna. V.66, n.3, p.192-195. 2010.

MILlER, A. N., E. J. WILliAMS, K. SIBLEY, S. HERATH, E. A. LANE, J. FISHWICK, D. M. NASH, A. N. RYCROFT, H. DOBSON, C. E. BRYANT AND I. M. SHELDON. The effects of Arcanobacterium pyogenes on endometrial function in vitro, and on uterine and ovarian function in vivo. Theriogenology. V.68, p.972-980. 2007.

LUCY M. C. Reproductive loss in high-producing dairy cattle: where will it end? Journal Dairy Science. v.84, p.1277-93. 2001.

MARTINEZ, N., C. A. RISCO, F. S. LIMA, R. S. BISINOTTO, L. F. GRECO, E. S. RIBEIRO, F. MAUNSELL, K. GALVAO AND J. E. SANTOS. Evaluation of peripartal 
calcium status, energetic profile, and neutrophil function in dairy cows at low or high risk of developing uterine disease. Journal Dairy Science. v.95, p.7158-7172. 2012.

MILLER HV, KIMSEY PB, KENDRICK JW, DARIEN B, FRANTI C, HORTON J. Endometritis of dairy cattle: diagnosis, treatment and fertility. Bovine Practcies. v.15:, p.323. 1980.

WILLIAMS, E. J, D. P. FISCHER, D. U. PFEIFFER, G. C. W. ENGLAND, D. E. NOAKES AND I. M. SHELDON. Clinical evaluation of postpartum vaginal mucus reflects uterine bacterial infection and the immune response in cattle. Theriogenology v.63, p.102-117. 2005.

WILLIAMS, E. J., D. P. FISCHER, D. E. NOAKES, G. C. ENGLAND, A. RY- CROFT, H. DOBSON, AND I. M. SHELDON. The relationship be- tween uterine pathogen growth density and ovarian function in the postpartum dairy cow. Theriogenology v.68, p.549-559. 2007.

WITTROCK, J. M., K. L. PROUDFOOT, D. M. WEARY AND M. A. VON KEYSERLINGK. Short communication: Metritis affects milk production and cull rate of Holstein multiparous and primiparous dairy cows differently Journal Dairy Science v.94, p.2408-2412. 2011.

MARKUSFELD, O. Factors responsible for post parturient metritis in dairy cattle. Veterinary Rechearch. V.114, p.539-542. 1984.

MATEUS L., L. LOPES DA COSTA, F. BERNARDO, AND J. ROBALO SILVA.. Influence of puerperal uterine infection on uterine invo- lution and postpartum ovarian activity in dairy cows. Reproduction Domestic Animals. V.37, p.31-35. 2002a

MERRILL, R. M. 2013. INTRODUCTION TO EPIDEMIOLOGY. 6TH ED. JONES \& BARTLETT LEARNING, BURLINGTON, MASS MOREIRA, F., C. ORLANDI, C. A. RISCO, R. MATTOS, F. LOPES, AND W. W. THATCHER. Effects of presynchronization 
and bovine somatotropin on pregnancy rates to a timed artificial insemination protocol in lactating dairy cows. Journal Dairy Science. v.84, p.1646-1659. 2001.

NORMAN, H. D., J. R. WRIGHT, S. M. HUBBARD, R. H. MILLER, AND J. L. HUTCHISON..Reproductive status of Holstein and Jersey cows in the United States. Journal Dairy Science. v.92, p.3517-3528. 2009.

NOAKES, D. E., L. WALLACE AND G. R. SMITH. Bacterial flora of the uterus of cows after calving on two hygienically contrasting farms. Veterinary Recharch. V.128, p.440-442. 1991.

NOAKES, D. E.; PARKINSON, T. J. \& ENGLAND, G. C. W. The puerperium and the care of the newborn. In: D. E. Noakes, T. J. Parkinson \& G. C. W. England, Arthur`s Veterinary Reproduction and Obstetrics, 8ed., p 189-202. China: W. B.Saunders. 2001a.

OIKONOMOU, G., A. G. TEIXEIRA, C. FODITSCH, M. L. BICALHO, V. S. MACHADO, AND R. C. BICALHO. Fecal microbial diversity in pre-weaned dairy calves as described by pyrosequencing of metage- nomic 16S rDNA. Associations of Faecalibacterium species with health and growth. PLoS One 8:e63157. 2013.

OPSOMER G, GROHN YT, HERTL J, CORYN M, DELUYKER H, DE KRUIF A. Risk factors for post partum ovarian dysfunction in high producing dairy cows in Belgium: a field study. Theriogenology 2000;53:841-57.

OVERTON, M. AND J. FETROW. 2008. Economics of postpartum uterine health. Page 3943 in Dairy cattle reproduction council convention, Omaha NE, USA.

PETER AT, BOSU WTK, DEDECKER RJ. Suppression of preovulatory luteinizing hormone surges in heifers after intrauterine infusions of Escherichia coli endotoxin. Am J Vet Res 1989;50:368-73.

POTTER, T. J., J. GUITIAN, J. FISHWICK, P. J. GORDON AND I. M. SHELDON. 2010. Risk factors for clinical endometritis in postpartum dairy cattle. Theriogenology. 74:127-134. 
PURSLEY, J. R., M. O. MEE, AND M. C. WILTBANK. 1995. Synchronization of ovulation in dairy cows using PGF2alpha and GnRH. Theriogenology 44:915-923.

RADOSTITS, O. M.; GAY, C. C.; BLOOD, D. C. \& HINCHCLIFF, K. W. (2002). Estados sistémicos gerais. In O. M. Radostits, C. C. Gray, D. C. Blood \& K. W. Hinchcliff, Clínica Veterinária: Um tratado de doenças dos Bovinos, Ovinos, Suínos, Caprinos e Equinos (9thed). (pp 36-99). Rio de Janeiro: Guanabara Koogan S. A.

RISCO, A. C.; YOUNGQUIST, R. S. \& SHORE, M. D. Postpartum uterine infections. In R. S. Yongquist \& W. R. Threlfall, Current Therapy in Large Animal Theriogenology. 2ed.,p. 339-344, USA, Saunders Elsevier. 2007.

ROCHA, A.; CARVALHEIRA J. Parâmetros reprodutivos e eficiência de inseminadores em explorações de bovinos de leite em Portugal. In: CONGRESSO DE CIÊNCIAS VETERINÁRIAS, 2002, Oeiras. Anais... Oeiras: SPCV,. p. 129-138. 2002.

ROCHE, J. R., N. C. FRIGGENS, J. K. KAY, M. W. FISHER, K. J. STAFFORD AND D. P. BERRY. 2009. Invited review: Body condition score and its association with dairy cow productivity, health, and welfare. Journal Dairy Science. 92:5769-5801.

ROYAL M.D., R.F. SMITH, AND N.C. FRIGGENS. 2008. Fertility in dairy cows: bridging the gaps. Animal 2:1101-1103.

RUDER, C. A., R. G. SASSER, R. J. WILliAMS, J. K. ELY, R. C. BULL, AND J. E. BUTLER. 1981. Uterine infection in postpartum cows II possible synergistic effect of fusobacterium necrophorum and Corynebacterium pyogenes. Theriogenology 15:573-580.

SANTOS, T. M. A, L. S. CAIXETA, V. S. MACHADO, A. K. RAUF, R. O. GILBERT, R. C. BICALHO. 2010. Antimicrobial resistance and presence of virulence factor genes in Arcanobacterium pyogenes isolated from the uterus of postpartum dairy cows.

Veterinary Microbiology. 145: 84-89. 
SANTOS, T. M., AND R. C. BICALHO. 2012. Diversity and succession of bacterial communities in the uterine fluid of postpartum metritic, endometritic and healthy dairy cows. PLoS One 7:e53048.

SCHUENEMANN, G. M., I. NIETO, S. BAS, K. N. GALVAO AND J. WORKMAN. 2011. Dairy calving management: Effect of perineal hygiene scores on metritis.. Journal Dairy Science 94:(E-Suppl. 1) 744.

SMITH, B. I. \& RISCO, C. A. (2002). Predisposing factors and potential causes of postpartum metritis in dairy cattle. Compendium on Continuing Education Practicing Veterinarian. 24, 74-80

SEMAMBO DK, AYLIFFE TR, BOYD JS, TAYLOR DJ. Early abortion in cattle induced by experimental intrauterine infection with pure cultures of Actinomyces pyogenes. Veterinary Record 1991;129:12-6.

SILVA N, LOBATO FC. Isolation and antimicrobial susceptibility of bacteria recovered from uteri of dairy cows with post-partum endometritis. Revista Brasileira de Reprodução Animal ; 23: 410-411. 1998.

SILVA, E., S. LEITAO, T. TENREIRO, C. POMBA, T. NUNES, L. LOPES DA COSTA AND L. MATEUS. Genomic and phenotypic characterization of Escherichia coli isolates recovered from the uterus of puerperal dairy cows. Journal Dairy Science. v.92, p.60006010. 2009.

SHELDON IM, NOAKES DE, RYCROFT AN, PFEIFFER DU, DOBSON H. Influence of uterine bacterial contamination after parturition on ovarian dominant follicle selection and follicle growth and function in cattle. Reproduction;v.123, p.837-45. 2002

SHELDON IM, NOAKES DE, RYCROFT AN, DOBSON H. The effect of intrauterine administration of estradiol on postpartum uterine involution in cattle. Theriogenology;v.59, p.1357-71. 2003 
SHELDON IM, DOBSON H. Postpartum uterine health in cattle. Animal Reproduction Science;v.82, n.83, p.295-306. 2004

SHELDON, I. M., G. S. LEWIS, S. LEBLANC, AND R. O. GILBERT. Defining postpartum uterine disease in cattle. Theriogenology v.65, p.1516-1530. 2006.

SHELDON IM, WILLIAMS EJ, MILLER AN, NASH DM, HERATH S. Uterine diseases in cattle after parturition. Veterinary Journal v.176, p.115-121. 2008.

SHELDON IM, WILLIAMS EJ, MILLER AN, NASH DM, HERATH S. Uterine diseases in cattle after parturition. Veterinary Journal n.176, p.115-121. 2008.

SHELDON, I. M., J. CRONIN, L. GOETZE, G. DONOFRIO, H-J. SCHUBERT. Review. Defining postpartum uterine disease and the mechanisms of infection and immunity in the female reproductive tract in cattle. Reproduction Domestic Animals. V.44, p.1-9. 2009.

STEVENS, R. B. Cultural practices in disease control. In: Horsfall JG Dimond AE (Ed.). Plant Pathology: an Advanced Treatise. New York, NY: Academic Press. v.3, p.357-429. 1960.

STUDER E, Morrow DA. Postpartum evaluation of bovine reproductive potential: comparison of findings from genital tract examination per rectum, uterine culture, and endometrial biopsy. Journal of the American Veterinary Medical Association; v.172, p.489-94. 1978.

SWARTZ, J. D., M. LACHMAN, K. WESTVEER, T. O’NEILL, T. GEARY, R. W. KOTT, J. G. BERARDinElLi, P. G. HATFIELD, J. M. THOMSON, A. ROBERTS, AND C. J. YEOMAN. Characterization of the vaginal microbiota of ewes and cows reveals a unique microbiota with low levels of Lactobacilli and near-neutral $\mathrm{pH}$. Frontiers Veterinary Science. v.1, p.19. . 2014. 
TRINDER N, HALL RJ, RENTON CP.. The relationship between the intake of selenium and vitamin E on the incidence of retained placenta in dairy cows. Vet Record, v.93, p.641-643. 1973.

WILLIAMS, E. J, D. P. FISCHER, D. U. PFEIFFER, G. C. W. ENGLAND, D. E. NOAKES AND I. M. SHELDON. Clinical evaluation of postpartum vaginal mucus reflects uterine bacterial infection and the immune response in cattle. Theriogenology v.63, p. 102-117. 2005.

VAZQUEZ-AÑON M, BERTICS S, LUCK M, GRUMMER RR, PINHEIRO J. Peripartum liver triglyceride and plasma metabolites in dairy cows. Journal Dairy Science, v.77, p.15211528. 1994.

WANG, Y., B. N. AMETAJ, D. J. AMBROSE, AND M. G. GANZLE. Characterisation of the bacterial microbiota of the vagina of dairy cows and isolation of pediocin-producing Pediococcus acidilactici. BMC Microbiology. v.13, p.19. 2013. 